\title{
Recent approaches in nitrogen management for sustainable agricultural production and eco-safety
}

\author{
Ram A. Jat ${ }^{\mathrm{a}, \mathrm{b} *}$, Suhas P. Wani ${ }^{\mathrm{a}}$, Kanwar L. Sahrawat ${ }^{\mathrm{a}}$, Piara Singh ${ }^{\mathrm{a}}$, S.R. Dhaka ${ }^{\mathrm{c}}$ \\ and B.L. Dhaka ${ }^{\mathrm{d}}$ \\ ${ }^{a}$ International Crops Research Institute for the Semi-Arid Tropics, Patancheru 502 324, India; \\ ${ }^{b}$ Navsari Agricultural University, Navsari 396 450, India; ${ }^{c}$ SK Rajasthan Agricultural \\ University, Bikaner 334 006, India; ${ }^{d}$ Maharana Pratap University of Agriculture and \\ Technology, Udaipur 313 0013, India
}

(Received 21 June 2010; final version received 13 January 2011)

\begin{abstract}
Among plant nutrients, nitrogen $(\mathrm{N})$ is the most important. Its importance as a growth- and yield-determining nutrient has led to large and rapid increases in $\mathrm{N}$ application rates, but often with poor use efficiency. Nitrogen management requires special attention in its use so that the large losses can be minimized and the efficiency maximized. Site-specific nutrient management (SSNM) has been found especially useful to achieve the goals of improved productivity and higher $\mathrm{N}$ use efficiency (NUE). Leaf color charts and chlorophyll meters assist in the prediction of crop $\mathrm{N}$ needs for rice and wheat, leading to greater $\mathrm{N}$-fertilizer efficiency at various yield levels. Crop simulation models can be used in combination with field information and actual weather data to make recommendations to achieve higher NUE. Remote sensing tools are also used to predict crop $\mathrm{N}$ demands precisely. At the same time, traditional techniques like balanced fertilization, integrated $\mathrm{N}$ management (INM), use of nitrification inhibitors and slow-release nitrogenous fertilizers (SRNF), split application and nutrient budgeting, among others, are also used to supplement recent $\mathrm{N}$ management techniques to attain higher productivity and NUE, and reduce environmental pollution through the leakage of fertilizer $\mathrm{N}$.
\end{abstract}

Keywords: controlled-release $\mathrm{N}$ fertilizers; eco-safety; nitrogen; nitrogen use efficiency; sustainability

\section{Introduction}

Currently, the world, including countries like India, is facing the unprecedented challenge of substantially increasing agricultural production to secure food for the 80 million individuals joining our population each year. According to FAO estimates, we need to double food production in the next 40 years to achieve food security. In other words, what agricultural production was achieved between the beginning of agriculture 10,000 years ago and today, must be achieved again in the next 40 years (Wade 2009). To accomplish this gigantic task, special attention is required on nutrient management, water management, plant protection, and the development of

*Corresponding author. Email: ra.jat@cgiar.org 
new crop cultivars with greater yield potential, suited to specific agro-climatic conditions, and strengthening of the extension agencies.

Among the plant nutrients, $\mathrm{N}$ is most important from the plant nutrition point of view. Amino acids, proteins, carriers, enzymes, regulators, nucleic acids, pigments, alkaloids and many other metabolites involve $\mathrm{N}$ in their biosynthesis and interconversions (Marschner 1997; Srivastava and Singh 1999). Because soils all over the world are universally deficient in $\mathrm{N}$ to varying degrees, it is also the nutrient applied in most quantity from external sources (Wade 2009). Modern agricultural systems depend heavily on large inputs of $\mathrm{N}$ fertilizer to maintain productivity, because naturally fixed $\mathrm{N}$ is seldom adequate for high-production systems (Dinnes et al. 2002; Evenson and Gollin 2003).

In many ways, $\mathrm{N}$ fertilizer is an important tool for economic development and lifestyle improvement, especially in economies with a large agrarian base. However, its importance as a growth- and yield-determining nutrient has led to large and rapid increases in $\mathrm{N}$ application rates, often with very poor efficiencies of use. In the quest to achieve high yields of crops, particularly rice (Oryza sativa L.) and wheat (Triticum aestivum L.), farmers in many parts of the world tend to apply $\mathrm{N}$ far in excess of requirements (Prasad 2005; Pathak et al. 2006). This is particularly true in sequentially grown rice and wheat systems in the Indo-Gangetic plain in the northwestern India, leading to further lowering of the $\mathrm{N}$ fertilizer recovery efficiency (RE), which does not exceed 50\% (Katyal et al. 1985; Bijay-Singh et al. 2001). Diagnostic surveys on nutrient management prevailing in areas of western Uttar Pradesh, India dominated by rice-wheat cropping systems (RWCS), revealed that nearly one-third of farmers practicing RWCS apply as much as $180 \mathrm{~kg}$ fertilizer $\mathrm{N} \mathrm{ha}^{-1}$ to each rice and wheat crop against a local recommendation of $120 \mathrm{~kg} \mathrm{~N}^{-1}$ (Dwivedi et al. 2001). Fertilizer use efficiency in the coarse-textured permeable soils is very low $(21-31 \%$ in rice and $32-52 \%$ in wheat) due to excessive N losses (Katyal et al. 1985; Aulakh and Bijay-Singh 1997; Cassman et al. 2002). Wang et al. (2001) reported from their on-farm studies that current $\mathrm{N}$ management practices in southeast China are inconsistent with the physiological $\mathrm{N}$ requirements of the rice crop and lead to large $\mathrm{N}$ losses. Nitrogen supply appears to be excessive during early vegetative growth but deficient during grain filling. A review by Ladha et al. (2005) on nitrgen use efficiency (NUE) showed that for wheat and rice average single-year fertilizer $\mathrm{N}$ recovery efficiencies in the experimental plots were 57 and $46 \%$, respectively. Nitrogen recovery in crops grown by farmers is often much lower. A review of the best available information suggests that the average recovery efficiency of nitrogen (REN) for fields managed by farmers ranged from 20 to $30 \%$ under rainfed conditions and from 30 to $40 \%$ under irrigated conditions (BijaySingh and Yadvinder-Singh 2008). NUE exceeding $40 \%$ is expected to occur in response to improved $\mathrm{N}$ management practices. Cassman et al. (2002) found that $\mathrm{N}$ recovery for rice from on-farm locations averaged $31 \%$ under irrigated conditions in Asia and $40 \%$ under field-specific management practices. For wheat grown in India, recovery averaged $18 \%$ under poor weather conditions, but increased to $49 \%$ when grown under good weather conditions (Table 1). Ladha et al. (2005) compiled data on ${ }^{15} \mathrm{~N}$ recovery by cereal crops and found that average $\mathrm{REN}^{-15} \mathrm{~N}$ was $44 \%$ in the first growing season and total recovery of ${ }^{15} \mathrm{~N}$ fertilizer in the first plus five subsequent crops was only $\sim 50 \%$. Assuming that the amount of ${ }^{15} \mathrm{~N}$ in the roots is negligible in the sixth growing season, the remaining $50 \%$ of the ${ }^{15} \mathrm{~N}$ fertilizer would have either become part of the soil organic matter (SOM) pool as a 
result of immobilization or was lost from the soil-crop system (Jansson and Persson 1982).

When $\mathrm{N}$ application is not synchronized with crop demand, $\mathrm{N}$ losses from the soil-plant system are large, leading to low NUE. N productivity has declined sharply since the widespread use of $\mathrm{N}$ started with the Green Revolution (Figure 1). Even since 1980, the N productivity has decreased by 50\% (Bijay-Singh and YadvinderSingh 2008). Nitrogen fertilizer, being a basic and widely applied nutrient in agriculture, needs special attention for its management. The fertilizer industry faces a permanent challenge to improve the efficiency of its products. This is done through either the improvement of fertilizers already in the use or the development of new specific fertilizer types (Trenkel et al. 1988). Nitrogen management is important not only for sustaining agricultural production, but also from an eco-safety point of view because the release of $\mathrm{N}$ into the environment leads to various ecological and health problems (FAO 2001). Nitrogen should be applied only in required amounts for optimizing supply and demand according to their variation in time and space (Ahlawat 2008).

Hence, there is a need to increase fertilizer NUE, and not just application rates, to sustain productivity levels, and also to minimize environmental hazards. There is no universally accepted scientific definition of nutrient efficiency or NUE. Under practical conditions, nutrient efficiency concerns the amount of nutrients taken up from the soil by plants and crops within a certain period compared with the amount

Table 1. Nitrogen fertilizer recovery (REN) by rice and wheat from on-farm measurements.

\begin{tabular}{|c|c|c|c|c|}
\hline Crop & Region & $\begin{array}{l}\text { Number } \\
\text { of farms }\end{array}$ & $\begin{array}{c}\text { Average } \mathrm{N} \\
\text { levels } \\
\mathrm{kg} \mathrm{N} \mathrm{ha}^{-1} \\
( \pm \mathrm{SD})\end{array}$ & $\begin{array}{c}\mathrm{REN}(\%) \\
( \pm \mathrm{SD})\end{array}$ \\
\hline \multirow[t]{2}{*}{ Rice } & Asia - farmers' practice & 179 & $117 \pm 39$ & $31 \pm 18$ \\
\hline & Asia-field-specific management & 179 & $117 \pm 39$ & $40 \pm 18$ \\
\hline \multirow[t]{2}{*}{ Wheat } & India - unfavourable weather & 23 & $145 \pm 31$ & $18 \pm 11$ \\
\hline & India - favourable weather & 21 & $123 \pm 20$ & $49 \pm 10$ \\
\hline
\end{tabular}

Source: Cassman et al. (2002).

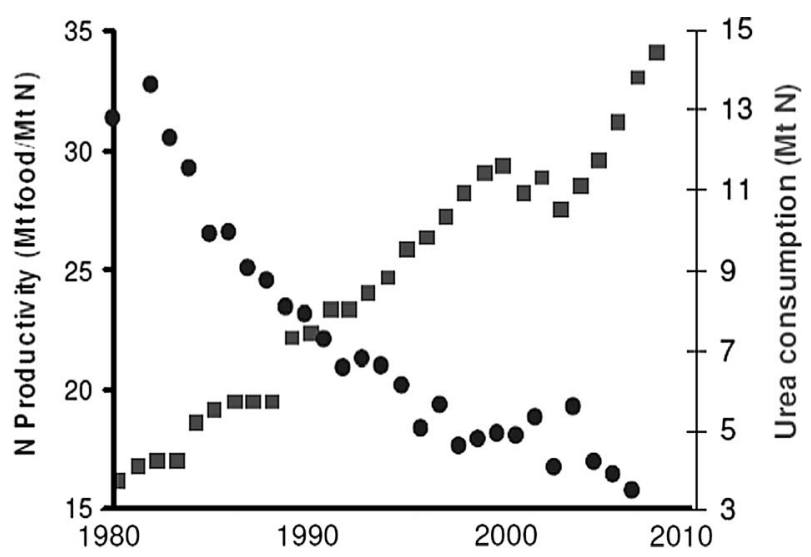

Figure 1. Nitrogen productivity over the years in India (Wade 2009). 
of nutrients available from the soil or applied during that same period (Trenkel 1997). Fertilizer $\mathrm{N}$ is mainly lost after its application in the field through the mechanisms of $\mathrm{NH}_{3}$ volatilization, $\mathrm{NO}_{3}^{-}$leaching and denitrification (Table 2). Therefore, when developing any effective strategy for achieving higher NUE, the N loss processes need to be considered. The inhibition of nitrification offers the most potential in the $\mathrm{N}$ cycle for enhancing NUE by reducing $\mathrm{N}$ losses via leaching and denitrification, which occur following the nitrification of ammonium or urea applied or produced by the mineralization of organic N in the soil (Sahrawat 1989; Subbarao et al. 2006). Modern high-production agricultural systems result in conditions that enhance nitrification, lower NUE and reduce SOM (McGill et al. 1981; Peng et al. 2005). The rapid conversion of $\mathrm{NH}_{4}^{+}$to $\mathrm{NO}_{3}^{-}$in the soil limits the effectiveness of much of the applied $\mathrm{N}$ fertilizer (Subbarao et al. 2006). Nearly $90 \%$ of all the added $\mathrm{N}$ fertilizer is applied in the $\mathrm{NH}_{4}^{+}$form, which is mostly nitrified within four weeks after application (Sahrawat 1980, 2008). For most arable soils, nitrification is so universal and rapid that applications of $\mathrm{NH}_{4}^{+}-\mathrm{N}$ can generally be considered as almost being the equivalent of the application of $\mathrm{NO}_{3}^{-}-\mathrm{N}$ (Mason 1992; Strong and Cooper 1992).

\section{Environmental cost due to $\mathbf{N}$ loss}

The loss of $\mathrm{N}$ lowers the effectiveness of $\mathrm{N}$ fertilization and at the same time can have serious environmental implications when excess $\mathrm{N}$ enters the natural environment (Jarvis 1996). Nitrogen, the most widely applied plant nutrient, has until recently often been singled out for its adverse effects on the environment, as well as on human and animal health (Keeney 1997). Smil (1999) reported that human activities have roughly doubled the amount of reactive $\mathrm{N}$ entering the element's biospheric cycle.

Losses of $\mathrm{N}$ from agricultural use are problematic not only from an agronomic, but also from an environmental perspective. Nitrogen fertilizer use is the source for $39 \%$ of the total 1.8 million tonnes (Mt) of ammonia-N emissions and $73 \%$ of the total 0.51 Mt of nitrous oxide-N emissions in India (Wade 2009) (Figure 2). Together, the ammonia and nitrous oxide gas emissions linked to fertilizer use are equivalent to $5 \mathrm{Mt}$ of urea lost from India's agriculture after it is applied to the soil. Food production is also a major source of $\mathrm{NH}_{3}$, contributing $>50 \%$ of global emissions (FAO 2001). With fertilizer applications increasing substantially, especially in developing countries, nitrous oxide emissions from agriculture could double over the next 30 years. In the Netherlands, which has the world's most

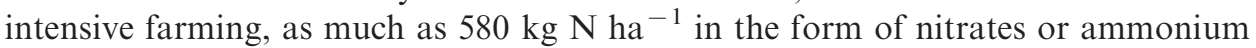
salts are applied every year as fertilizer, and at least $10 \%$ of that $\mathrm{N}$ goes straight back

Table 2. Loss of $\mathrm{N}$ through key loss processes following the application $120 \mathrm{~kg} \mathrm{~N}^{\mathrm{Na}}{ }^{-1}$ to lowland rice.

\begin{tabular}{lc}
\hline $\mathrm{N}$ form and process & $\mathrm{N}$ loss $\left(\mathrm{kg} \mathrm{N} \mathrm{ha}^{-1}\right)$ \\
\hline $\mathrm{NH}_{3}$ volatilization & 15 \\
$\mathrm{~N}_{2} \mathrm{O}$ denitrification & 30 \\
$\mathrm{NO}_{3}^{-}$leaching & 15 \\
Total losses $(50 \%$ of applied $\mathrm{N})$ & 60 \\
\hline
\end{tabular}

Source: Pathak et al. (2004). 
$39 \% \mathrm{NH}_{3}$ emission fom fertilizer use

Total emission: 1.8 Mt per year

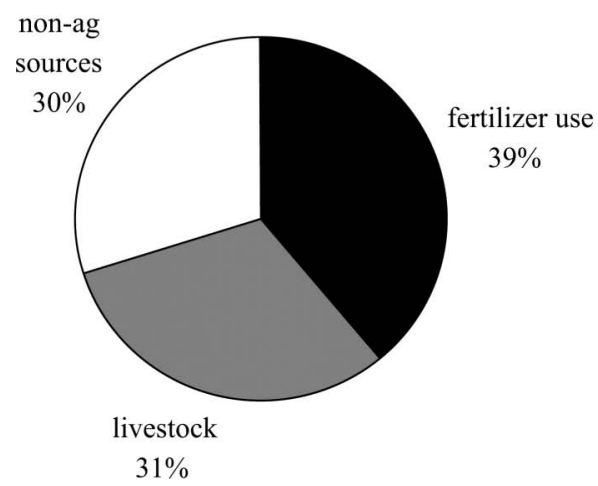

$73 \% \mathrm{~N}_{2} \mathrm{O}$ emission from $\mathrm{N}$ fertilizer use

Total emission: $0.51 \mathrm{Mt} N$ per year

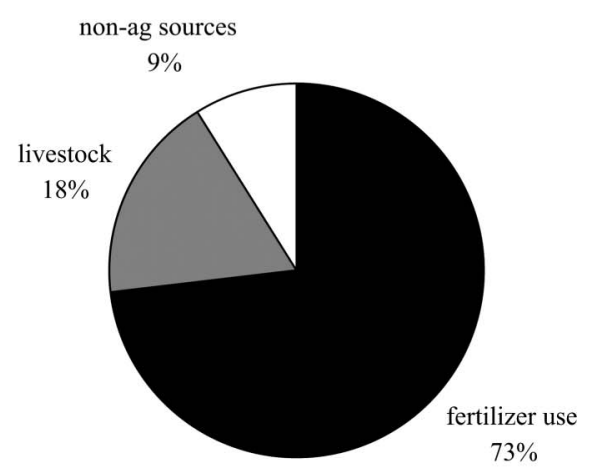

Figure 2. $\mathrm{NH}_{3}$ and $\mathrm{N}_{2} \mathrm{O}$ emission from $\mathrm{N}$ fertilizer use in India (Wade 2009).

into the atmosphere, either as ammonia or nitrous oxide (Moser et al. 1991). Of the total $100 \mathrm{Mt} \mathrm{N}$ produced in 2005 , only $17 \%$ was taken up by crops and the remainder was somehow lost to the environment (Erisman et al. 2008). In highly permeable soil profiles with alternating aerobic and anaerobic soil conditions under rice, applied $\mathrm{N}$ is readily converted to $\mathrm{NO}_{-}$, which is prone to loss via leaching, denitrification or both (Sahrawat 1989; Aulakh and Bijay-Singh 1997; Bijay-Singh et al. 2001). Environmental pollution by nutrient leaching or run-off from rice fields has become an important concern across Asia (Zhang and Wang 1999; Dobermann et al. 2002; Bijay-Singh and Yadvinder-Singh 2003).

\section{Nitrogen management for higher efficiency and sustainability}

Despite remarkable developments in crop production over the past four decades, NUE or recovery, especially that of N, remained low (Shaviv 2005). This poses serious concerns regarding environmental health, energy and resource conservation, especially in light of the much greater $\mathrm{N}$ fertilizer use than removal, and considering the significant increase in nutrient application per unit area. Recovery of applied $\mathrm{N}$ with ${ }^{15} \mathrm{~N}$ labeled fertilizer varies from 18.9 to $41.8 \%$ in rice (Kai et al. 1983 ; Katyal et al. 1985; Goswami et al. 1988), 37.2\% in maize (Arora et al. 1980), 36\% in a cowpea-rice cropping system (John et al. 1989) and 49\% in a maize and bean intercropping system (Ssali 1990). Mean global ${ }^{15} \mathrm{~N}$ recovery values for maize, rice and wheat were reported to be 40,44 and $45 \%$ of the applied $\mathrm{N}$, respectively (Ladha et al. 2005). Using crop $\mathrm{N}$ uptake data and the amount of $\mathrm{N}$ consumed in a country, average recovery values of applied $\mathrm{N}$ are $56 \%$ in the USA (Howarth et al. 2002), $52 \%$ in Canada (Janzen et al. 2003) and $48 \%$ in India (Ladha et al. 2005). According to Smil (2002), the world average for $\mathrm{N}$ recovery is $50 \%$. A recent worldwide evaluation shows that fertilizer $\mathrm{N}$ recovery efficiency is $\sim 30 \%$ in rice and wheat with current practices (Krupnik et al. 2004). Scientists worldwide are working to develop novel techniques of $\mathrm{N}$ management to achieve the goal of higher NUE and sustainability and to reduce the $\mathrm{N}$ losses to the environment. In recent years the following approaches have been found particularly helpful to address these concerns. 


\section{Site-specific nitrogen management (SSNM)}

It is widely acknowledged that the current approach of fixed-rate, fixed-time (blanket) fertilizer application is not helpful in achieving higher NUE (Angus et al. 1990; Wopereis et al. 1999; Wang et al. 2001; Dobermann et al. 2002; Ladha et al. 2003; Pathak et al. 2003). This is mainly because this approach does not consider the existence of large variability in the inherent soil nutrient supply and site-specific crop responses to nutrients among farms (Timsina and Connor 2001). To address this concern, the original concept of site-specific nutrient management to manage among-farm nutrient variability, was developed in Asia for rice (Dobermann et al. 1996, 1998; Buresh et al. 2005). SSNM has been defined as the dynamic, field-specific management of nutrients in a particular crop or cropping system to optimize the supply and demand of nutrients according to their differences in cycling through soil-plant systems. A distinct feature of this SSNM approach is that it adds important regional and real-time components to the otherwise used approaches of SSNM in large-scale farming, which mainly focus on managing spatial variability in nutrients within large production fields using highly advanced tools (Pierce and Nowak 1999; Robert 2002). In SSNM, prescriptive N management relies on earlier information on the average native soil $\mathrm{N}$, crop $\mathrm{N}$ need and its duration, while the corrective $\mathrm{N}$ management is based on the diagnostic tools such as a chlorophyll meter/SPAD meter, and leaf color chart (LCC). Gill et al. (2009) reported that maximum $\mathrm{N}, \mathrm{P}$ and $\mathrm{K}$ accumulation by crop was registered in SSNM, followed by improved state recommendations (ISR), and it was lowest in the farmers' fertilization practice (FFP) (Table 3). NPK use efficiency was much higher in SSNM compared with FFP. Addition of micronutrients in SSNM also increased internal NUE over the ISR. However, the magnitude of this increase varied among cropping systems. Similarly, work done by Shukla et al. (2004) on the productivity and profitability of hybrid rice-wheat cropping system under site-specific nutrient management practices, indicated that the SSNM package resulted in significant yield advantages in both rice and wheat compared with soil testing laboratory recommendation (STLR), local ad hoc recommendation (LAR) and farmers' fertilizer practice. Fertilizer recommendations based on SSNM and LCC techniques are more flexible and meet the crop demand, resulting in a crop yield increment of up to $0.3-0.5 \mathrm{tha}^{-1}$ and a saving of up to $20-30 \%$ fertilizer application (Hach and Tan 2007). Khurana et al. (2008) reported a significant increase in NUE in rice and wheat through the field-specific $\mathrm{N}$ management practiscd in the SSNM treatment in Punjab, India. In general, compared with the FFP, less fertilizer $\mathrm{N}$ was applied, and agronomic $\mathrm{N}$ use efficiency (AEN), recovery efficiency of fertilizer $\mathrm{N}$ (REN) and physiological efficiency of $\mathrm{N}$ (PEN) were significantly increased with SSNM. On average, AEN was increased by $7.3 \mathrm{~kg} \mathrm{~kg}^{-1}$ (83\%) and $5.3 \mathrm{~kg} \mathrm{~kg}^{-1}(63 \%)$, REN by $0.10 \mathrm{~kg} \mathrm{~kg}^{-1}(50 \%)$ and $0.10 \mathrm{~kg} \mathrm{~kg}^{-1}(59 \%)$, and PEN by $9.5 \mathrm{~kg} \mathrm{~kg}^{-1}(27 \%)$ and $7.7 \mathrm{~kg} \mathrm{~kg}^{-1}(26 \%)$ in rice and wheat crops, respectively. This increase was attributed to more uniform $\mathrm{N}$ applications among sites under the SSNM compared with FFP. Also, $\mathrm{N}$ applications were spread more evenly through the growing season and avoided heavy single applications at early growth stages of rice and wheat crops when compared with FFP. Even though SSNM led to a small increase in average fertilizer cost, a comparatively larger increase in gross returns over the fertilizer in wheat and rice was achieved compared with that under FFP. The increase in average fertilizer cost under SSNM was mainly attributed to an increase in K fertilizer use, 


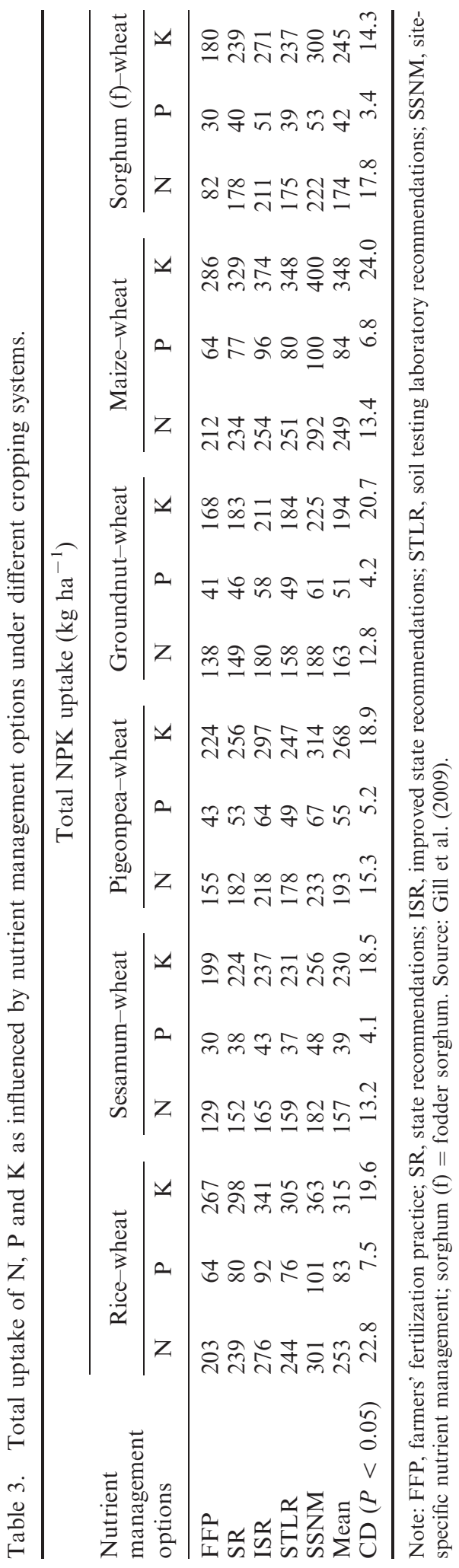


which is generally skipped by farmers in the Punjab (India). Khurana et al. (2007) also reported significant increases in NUE through the field-specific N management practiced in the SSNM treatment compared with the FFP. Wang et al. (2001) found significant increases in NUE through the field- and season-specific $\mathrm{N}$ management practiced in the SSNM treatment. In general, compared with the FFP, less N fertilizer was applied, and AEN, REN and partial factor productivity of $\mathrm{N}\left(\mathrm{PFP}_{\mathrm{N}}\right)$ were significantly increased. Across all four crops grown, AEN increased by $5 \mathrm{~kg}$ $\mathrm{kg}^{-1}(78 \%, P=0.000)$, REN by $0.11 \mathrm{~kg} \mathrm{~kg}^{-1}(61 \%, P=0.000)$ and $\mathrm{PFP}_{\mathrm{N}}$ by $12 \mathrm{~kg} \mathrm{~kg}^{-1}(33 \%, P=0.000)$. In SSNM, N application is spread over time, depending on the indigenous $\mathrm{N}$ supply and SPAD readings, which also helps to fine tune the $\mathrm{N}$ application according to weather conditions. For example, Wang et al. (2001) reported that farmers applied their usual high amounts of $\mathrm{N}$ (average $170 \mathrm{~kg}$ $\mathrm{N} \mathrm{ha}{ }^{-1}$ ), all at early stages of the crop, despite the low climatic yield potential due to poor weather later in the crop season. By contrast, only $115 \mathrm{~kg} \mathrm{~N} \mathrm{ha}^{-1}$ was applied in the SSNM treatment, based on knowledge of the SPAD readings at critical growth stages, resulting in AEN and REN almost twice that of FFP. Compared with FFP, $\mathrm{N}$ applications in the SSNM treatment were more uniform among farms, spread more evenly through the growing season, and avoided heavy single applications at early growth stages.

\section{Chlorophyll meter and leaf color chart (LCC) guided recommendations}

Although generally good correlations with grain yield have been observed with methods based on soil tests and laboratory analyses of tissue samples to predict cereal N needs during the vegetative growth stages (Fox et al. 1989; Hong et al. 1990; Magdoff et al. 1990; Justes et al. 1997; Lemaire and Gastal 1997), they are time consuming, cumbersome and expensive. The prospects remain bleak for accurate $\mathrm{N}$ prescriptions developed using soil tests prior to the cropping season. Bijay-Singh (2008) argued that recommendations based on soil tests remain ignorant about the dynamics of $\mathrm{N}$ release from crop residues, organic manures and irrigation water, and are not very successful in rice and wheat. Similarly, Stalin et al. (1996) and Adhikari et al. (1999) have also expressed that soil tests for $\mathrm{N}$ fertilizer recommendation in flooded rice soils have not been successful. Tissue tests are also less useful for the support of decisions on $\mathrm{N}$ supplementation than indicators that are directly related to the measurement of leaf and canopy greenness (Schröder et al. 2000). Thus, farmers often apply nitrogenous fertilizers over and above the recommended doses to ensure higher yields by avoiding the risk of $\mathrm{N}$ deficiency. The main reason for low $\mathrm{N}$-use efficiency is inefficient splitting of $\mathrm{N}$ applications, including the use of $\mathrm{N}$ in excess of requirements. There is a need to synchronize $\mathrm{N}$ application with crop demand. In addition to field-to-field variability, strategies for fertilizer $\mathrm{N}$ management must be responsive to temporal variations in crop $\mathrm{N}$ demand and soil $\mathrm{N}$ supply to achieve supply-demand synchrony and minimize $\mathrm{N}$ losses. Peng and Cassman (1998) demonstrated that the RE of top-dressed urea during a panicle initiation stage could be as high as $78 \%$. Hence, plant-need-based application of $\mathrm{N}$ is crucial for achieving high yield and NUE. To improve NUE and reduce $\mathrm{N}$ losses to the environment, precision tools, viz. LCC and a chlorophyll meter may be used widely at the farm level to optimize/synchronize $\mathrm{N}$ application with crop demand (Ahlawat 2008). The chlorophyll meter (SPAD-502, Minolta, Ramsey, NJ, USA), also known as a soil plant analysis development (SPAD) meter, can quickly and reliably assess 
the $\mathrm{N}$ status of a crop based on leaf area (Bijay-Singh 2008). It has been successfully used for rice (Balasubramanian et al. 1999; Hussain et al. 2000), corn (Zea mays L.) (Peterson et al. 1993) and wheat (Follett et al. 1992).

Two approaches have been used to apply fertilizer $\mathrm{N}$ in rice using a chlorophyll meter: (1) when the sufficiency index (defined as SPAD value of the plot in question divided by that of a well-fertilized reference plot or strip) falls below 0.90 (Hussain et al. 2000); and (2) when the SPAD value is less than the set critical reading. The sufficiency index approach of Hussain et al. (2000) may be disadvantageous because it requires a well-fertilized area. In another study carried out in southern India (IRRI-CREMNET 1998), a value of 37 was found to be critical for obtaining high yields and improved NUE in short-statured improved indica rice cultivars. These studies indicate the need to determine chlorophyll meter threshold values for different rice-growing environments. Bijay-Singh et al. (2002) reported that using the criteria of applying $30 \mathrm{~kg} \mathrm{~N}^{-1}$ each time the SPAD value falls below 37.5 always resulted in a rice grain yield equivalent to that obtained with $120 \mathrm{~kg} \mathrm{~N}^{-1}$ in three fixed-time splits (Table 4). In treatments receiving all $\mathrm{N}$ doses beginning 14 days after transplanting (DAT) at a critical SPAD value of 37.5 , rice grain yields equivalent to those produced by applying $120 \mathrm{~kg} \mathrm{~N} \mathrm{ha}^{-1}$ were obtained with $90 \mathrm{~kg} \mathrm{~N} \mathrm{ha}^{-1}$. As expected, the AE was greater when less $\mathrm{N}$ fertilizer was used, but this was achieved with the use of the chlorophyll meter without sacrificing yield. The threshold SPAD value of 35 for semi-dwarf indica rice varieties in transplanted rice systems during the dry season in the Philippines, has to be reduced to 32 during the wet season when solar radiation is relatively low (Balasubramanian et al. 1999). It has also been suggested that different threshold SPAD values may have to be used for different varietal groups (Balasubramanian et al. 2000; Thiyagarajan et al. 2000).

Chlorophyll meter-based $\mathrm{N}$ management saved $12.5-25 \%$ on the existing fertilizer $N$ recommendation (Bijay-Singh et al. 2002). Many farmers also apply a dose of $\mathrm{N}$ approximately 1 week after transplanting, in lieu of basal application. Because rice seedlings take $\sim 7$ days to recover from the transplanting shock (Meelu and Gupta 1980), it is very likely that most $\mathrm{N}$ applied around 7 DAT is not used by plants and is lost. Based on chlorophyll-guided studies, Bijay-Singh et al. (2002) suggested that: (1) a basal dose of $30 \mathrm{~kg} \mathrm{~N}^{-1}$ was not efficiently used by the crop and was possibly prone to loss or immobilization; and (2) N applied starting at 14 DAT based on the crop need determined by the chlorophyll meter, was used more efficiently.

However, the high cost of the chlorophyll meter keeps it out of reach of many Asian farmers. The LCC is an inexpensive alternative to the chlorophyll meter (Furuya 1987). Like the chlorophyll meter, the critical color shade on the LCC needs to be determined to guide $\mathrm{N}$ application to rice. It varies depending on the cultivar and crop-establishment method, but can be determined after one or two seasons of testing for local situations. Because shade 4 on the LCC represents greenness equivalent to a SPAD value between 35 and 37, it was found to be the threshold value for inbred rice varieties prevalent in the Indo-Gangetic plains in India (BijaySingh 2008). Results (Table 5) from Singh et al. (2005) on rice ('PB-1') grain yield and $\mathrm{N}$-use efficiency under different $\mathrm{N}$ management practices indicated a significant improvement in yield and agronomic efficiency of $\mathrm{N}$ with LCC-based $\mathrm{N}$ application compared with fixed time $\mathrm{N}$ application. Application of $30 \mathrm{~kg} \mathrm{~N}^{-1}$ at LCC 4 resulted in a total $\mathrm{N}$ application of $90 \mathrm{~kg} \mathrm{~N}^{-1}$ and a grain yield statistically similar to that obtained with $120 \mathrm{~kg} \mathrm{~N} \mathrm{ha}{ }^{-1}$ applied in recommended splits 


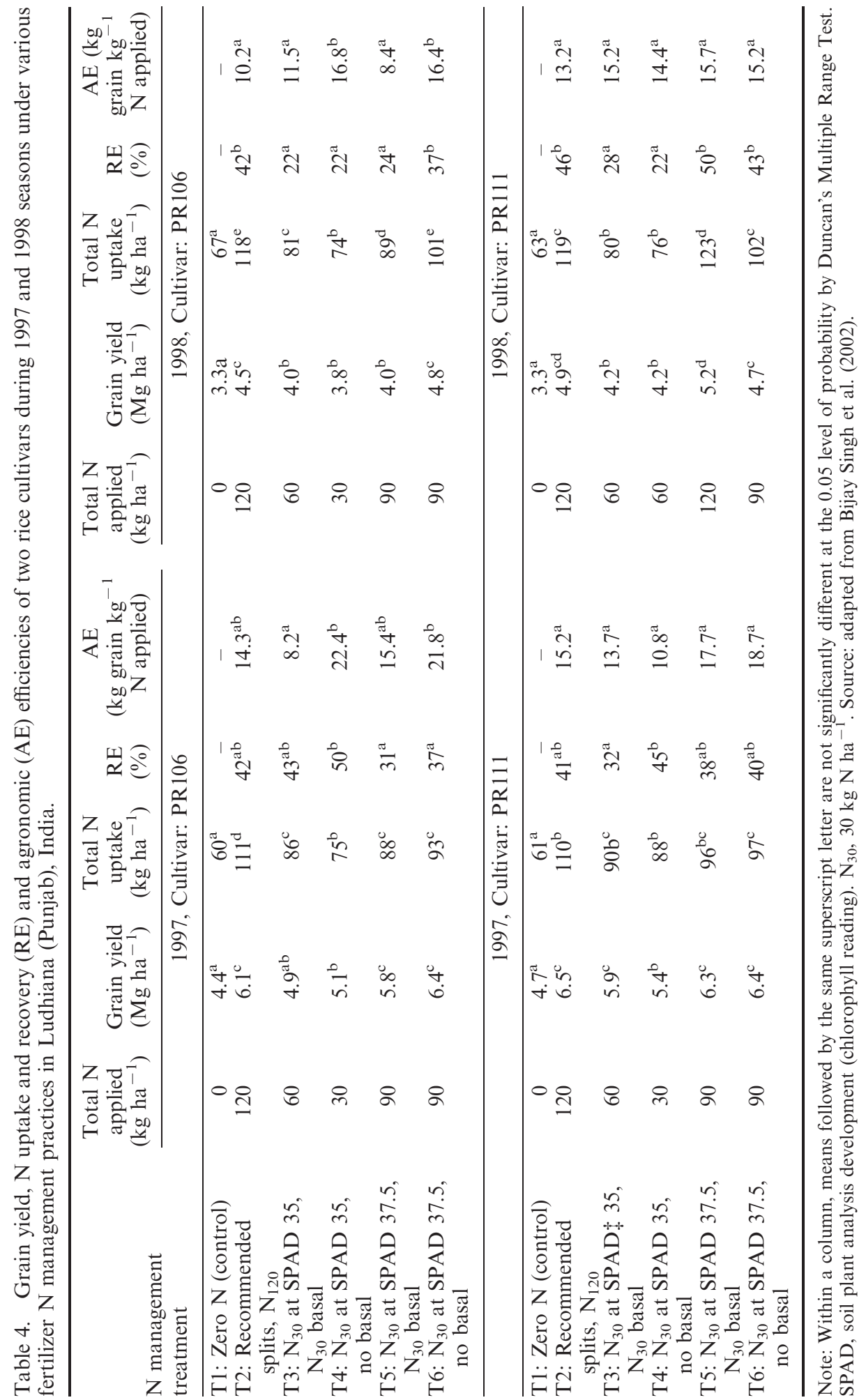


Table 5. Rice ('PB-1') grain yield and $\mathrm{N}$-use efficiency under different $\mathrm{N}$ management practices.

\begin{tabular}{lccc}
\hline N management practice & $\begin{array}{c}\text { Total N } \\
\text { applied } \\
\left(\mathrm{kg} \mathrm{ha}^{-1}\right)\end{array}$ & $\begin{array}{c}\text { Grain } \\
\text { yield } \\
\left(\mathrm{t} \mathrm{ha}^{-1}\right)\end{array}$ & $\begin{array}{c}\text { Agronomic } \\
\text { efficiency } \\
\left(\mathrm{kg} \mathrm{kg}^{-1} \mathrm{~N}\right)\end{array}$ \\
\hline No- N (control) & 0 & 2.75 & - \\
Recommended N management & 80 & 3.86 & 13.9 \\
LCC $<3$ (No basal N) & 80 & 4.18 & 17.9 \\
$80 \%$ basal + LCC < 3 & 104 & 3.62 & 8.4 \\
Farmers' practice (three splits) & 100 & 3.74 & 9.9 \\
\hline
\end{tabular}

Note: The results presented are the means of trials on 20 farmers' fields. LCC, leaf color chart. Source: Singh et al. (2005).

(Bijay-Singh et al. 2002). The chlorophyll or SPAD meter, and its inexpensive and simple alternative, the LCC can be used for rapid and reliable monitoring of relative greenness of the leaf as an indicator of leaf $\mathrm{N}$ status. These tools have provided an excellent opportunity in terms of developing real-time $\mathrm{N}$ management strategies for rice, but they do not take into account photosynthetic rates or the biomass production and expected yields for working out the fertilizer $\mathrm{N}$ requirements (Gupta 2006). Owing to continuous wet soil moisture regimes in the rice crop, fertilizer $\mathrm{N}$ can be applied at any time, which is not applicable for many upland crops. In upland crops, for fertilizer application to be effective, it must be synchronized with the irrigation cycle, which reduces the importance of these instruments for crops grown under rainfed conditions.

\section{Use of remote sensing and geographical information system (GIS)}

An improvement in the NUE can be achieved by using modern tools like remote sensing and GIS. The reflectance of near infrared radiation (NIR; 800-1000 nm) can be measured using remote sensing tools. This reflectance is correlated with plant $\mathrm{N}$ status, as shown by the greenness of the leaves (Gill et al. 2008). Recently, methods based on measurements of reflectance in the red (defined by chlorophyll content) and near infrared (defined by living vegetation) region of the electromagnetic spectrum for estimating the $\mathrm{N}$ requirement of crops using early season estimates of $\mathrm{N}$ uptake and potential yield have been developed. Normalized difference vegetative index (NDVI) based on the in-season sensor reading can predict biomass, plant $\mathrm{N}$ concentration and plant $\mathrm{N}$ uptake (Gupta 2006). The NDVI increases with increasing leaf greenness and green leaf area, and can be used as a guide for inseason $\mathrm{N}$ applications.

Spatial and temporal variability in the nutrient supply are the major reasons for variations in crop yield, which can be managed by dividing a heterogeneous field into supposedly uniform management zones. Management zones are created on the basis of information on crop yield, soil data or crop conditions by adopting remote sensing techniques. The data obtained are superimposed on a base map to create management zones using GIS. These management zone maps can be used for sitespecific input management rather than applying a uniform dose of fertilizer $\mathrm{N}$ over the entire field. Extensive research work through on-farm trials in the Indo-Gangetic Plains (IGP) has clearly demonstrated that these modern tools are effective for 
site-specific input management (Gill et al. 2008). The use of green seeker, which is also a hand-held instrument for measuring the NDVI at various critical growth stages, generates data for crop conditions (Gupta 2006; Singh et al. 2006). These NDVI data from a standard plot, which has been sufficiently fertilized with $\mathrm{N}$, can be compared with a reference plot for which the $\mathrm{N}$ requirement is to be determined. The use of green seeker helps in applying adequate $\mathrm{N}$ at specific crop growth stages in various management zones. In a study conducted at Modipuram, India, the INSEY [in season estimation of yield) - GY (grain yield)] relationship used for calculating the $\mathrm{N}$ fertilizer dose in rice was: $y=90.97 \times \mathrm{INSEY}-0.602$ at 54-57 days and $y=315.35 \times$ INSEY -0.958 at $41-43$ days. The same relationship for calculating $\mathrm{N}$ fertilizer dose in wheat was: $y=1978 \times$ INSEY 1.926 for Feekes $5 / 6$ and $y=6192.7 \times$ INSEY -1.605 for Feekes $7 / 8$. The INSEY (calculated as: NDVI/days from planting to sensing or emergence to sensing) is an excellent predictor of the yield potential or yield (grain or forage depending on the system) that is likely to result with no added input. Using such relationship, the maximum yield of rice $\left(9.06 \mathrm{t} \mathrm{ha}^{-1}\right)$ and wheat $\left(5.60 \mathrm{t} \mathrm{ha}^{-1}\right)$ can be achieved in the schedule for $\mathrm{N}$ application in rice with $143 \mathrm{~kg} \mathrm{~N}^{-1}$ applied at 7 (40 $\mathrm{kg}$ $\left.\mathrm{ha}^{-1}\right), 28\left(40 \mathrm{~kg} \mathrm{ha}^{-1}\right)$ and $49\left(63 \mathrm{~kg} \mathrm{ha}^{-1}\right)$ DAT and wheat with $130 \mathrm{~kg} \mathrm{ha}^{-1}$ applied at basal $\left(60 \mathrm{~kg} \mathrm{ha}^{-1}\right)$, crown root initiation $\left(60 \mathrm{~kg} \mathrm{ha}^{-1}\right)$ and Feekes $7 / 8$ days $\left(10 \mathrm{~kg} \mathrm{ha}^{-1}\right)$ (Tables 6 and 7$)$.

\section{Use of simulation models}

Complexities surrounding the nutrient dynamics in soil suggest that computer-based systems are useful for marshalling the relevant information and presenting data in a fashion that is helpful to a farmer or adviser. Such decision-support systems have taken various forms and differ in their level of sophistication (Kitchen and Goulding 2001). Most have been aimed at $\mathrm{N}$ because of the importance and complexity of the

Table 6. Grain yield under $\mathrm{N}$ fertilizer use with green seeker-based N-management options in transplanted rice.

\begin{tabular}{|c|c|c|c|c|c|c|c|}
\hline \multirow[b]{2}{*}{ Basal } & \multicolumn{6}{|c|}{ Fertilizer $\mathrm{N}\left(\mathrm{kg} \mathrm{ha}^{-1}\right)$} & \multirow{2}{*}{$\begin{array}{l}\text { Grain yield } \\
\left(\mathrm{t} \mathrm{ha}^{-1}\right)\end{array}$} \\
\hline & 7 DAT & $21 \mathrm{DAT}$ & $28 \mathrm{DAT}$ & $42 \mathrm{DAT}$ & $49 \mathrm{DAT}$ & Total & \\
\hline 0 & 0 & 0 & 0 & 0 & 0 & 0 & 4.90 \\
\hline 40 & 0 & 40 & 0 & 40 & 0 & 120 & 8.85 \\
\hline 20 & 0 & 40 & 0 & 25 (GS) & 0 & 85 & 8.23 \\
\hline 20 & 0 & 60 & 0 & 30 (GS) & 0 & 110 & 8.18 \\
\hline 30 & 0 & 30 & 0 & 40 (GS) & 0 & 100 & 7.92 \\
\hline 40 & 0 & 40 & 0 & 36 (GS) & 0 & 116 & 8.75 \\
\hline 0 & 20 & 0 & 40 & 0 & 79 (GS) & 139 & 8.23 \\
\hline 0 & 20 & 0 & 60 & 0 & 54 (GS) & 134 & 7.71 \\
\hline 0 & 30 & 0 & 30 & 0 & $76(\mathrm{GS})$ & 136 & 8.94 \\
\hline 0 & 40 & 0 & 40 & 0 & 63 (GS) & 143 & 9.06 \\
\hline 50 & 50 & 50 & 50 & 50 & 50 & 300 & 11.25 \\
\hline $\mathrm{CD}(P=0.05)$ & & & & 1.66 & & & \\
\hline
\end{tabular}

Note: DAT, days after transplanting; GS, green seeker-based application Source: Annual Report, PDCSR (2006-07). 
Table 7. Effect of green seeker-guided $\mathrm{N}$ fertilizer application on grain yield and $\mathrm{N}$-use efficiency of wheat.

\begin{tabular}{|c|c|c|c|c|c|c|}
\hline \multirow[b]{2}{*}{ Basal } & \multicolumn{4}{|c|}{ Fertilizer $\mathrm{N}\left(\mathrm{kg} \mathrm{ha}^{-1}\right)$} & \multirow{2}{*}{$\begin{array}{l}\text { Grain yield } \\
\left(\mathrm{t} \mathrm{ha}^{-1}\right)\end{array}$} & \multirow{2}{*}{$\begin{array}{l}\text { N-use efficiency } \\
\left(\mathrm{kg} \mathrm{kg}^{-1} \mathrm{~N}\right)\end{array}$} \\
\hline & CRI & Feekes $5 / 6$ & Feekes $7 / 8$ & Total & & \\
\hline 0 & 0 & 0 & 0 & 0 & 1.46 & \\
\hline 60 & 60 & 0 & 0 & 120 & 5.26 & 0.72 \\
\hline 75 & 75 & 0 & 0 & 150 & 5.57 & 0.74 \\
\hline 60 & 0 & 19 (GS) & 0 & 79 & 3.74 & 0.61 \\
\hline 80 & 0 & $15(\mathrm{GS})$ & 0 & 95 & 4.57 & 0.68 \\
\hline 100 & 0 & 11 (GS) & 0 & 111 & 4.96 & 0.71 \\
\hline 40 & 40 & 9 (GS) & 0 & 89 & 4.30 & 0.66 \\
\hline 50 & 50 & 7 (GS) & 0 & 107 & 5.27 & 0.72 \\
\hline 60 & 60 & 4 (GS) & 0 & 124 & 5.53 & 0.74 \\
\hline 60 & 0 & 0 & 24 (GS) & 84 & 3.68 & 0.60 \\
\hline 80 & 0 & 0 & 21 (GS) & 101 & 4.52 & 0.68 \\
\hline 100 & 0 & 0 & 18 (GS) & 118 & 4.73 & 0.69 \\
\hline 40 & 40 & 0 & 18 (GS) & 98 & 4.39 & 0.67 \\
\hline 50 & 50 & 0 & 14 (GS) & 114 & 5.42 & 0.73 \\
\hline 60 & 60 & 0 & $10(\mathrm{GS})$ & 130 & 5.60 & 0.74 \\
\hline
\end{tabular}

Note: CRI, crown root - initiation stage; GS, geen seeker - guided fertilizer application based on equation developed at Feekes 5/6 and 7/8. Source: Annual Report, PDCSR (2006-07).

dynamics of this element in soil. The soil $\mathrm{N}$ balance processes in the decisionsupport systems include root $\mathrm{N}$ uptake, mineralization, immobilization, nitrification, denitrification and $\mathrm{N}$ leaching. Decision support systems are sophisticated tools, often being driven by computer-simulation models, but usually deal with a single element such as N. SUNDIAL (Bradbury et al. 1993; Smith et al. 1996) has been released for farmers and advisers through the Rothamsted website (www.rothamsted.bbsrc.ac.uk/aen/sundial/sundial.htm). It differs from earlier recommendation systems in attempting to take explicit account of the weather following the application of fertilizer, and thus the potential supply of $\mathrm{N}$ to the plant from soil mineralization during the spring and summer. In this way, SUNDIAL tries to optimize the supply of $\mathrm{N}$ to the crop, but minimizes the potential for loss. The CROPGRO-legume model is a process-oriented, mechanistic model with subroutines that simulate crop development, carbon (C) balance, crop and soil $\mathrm{N}$ balance, and soil water balance. It can simulate $\mathrm{N}$ fixation in legumes and its relationship with $\mathrm{N}$ uptake by plants (Boote et al. 2009). WELL_N (Goodlass et al. 1997) tries to do much the same for the vegetable crops, and NCYCLE is an N-balance model that compares inputs and outputs in grassland systems for beef and dairy production (Scholefield et al. 1991). Most of these decision-support programs supply information not only about the fertilizer need or value, but also the potential for $\mathrm{N}$ losses (leaching and denitrification and, from MANNER software ammonia loss) (Kitchen and Goulding 2001). The NGAUGE decision-support system for grasslands has been developed from the NCYCLE model by Brown et al. (2005). The underlying empirically based model simulates monthly $\mathrm{N}$ flows within and between the main components of the livestock-production system according to the user inputs describing the site conditions and farm management characteristics. 


\section{Scope of nanoparticles/materials}

The emergence of nanotechnology and the development of new nanodevices and nanomaterials (Scott and Chen 2003; Joseph and Morrison 2006) have opened up potential novel applications in the plant nutrient management. These inexpensive nanotech materials applied to increase input use efficiency and crop productivity, will bring about major growth in agriculture in the near future. Many things must be addressed prior to the utilization of nanoparticles in agriculture. First, it is important to know whether nanoparticles have any phytotoxic effects. It may be possible that nanoparticles produce some local damage in cells, as reported for in vitro treatments (Pavel et al. 1999; Cotae and Creanga 2005; Pavel and Creanga 2005), but this does not mean that the whole plant would be affected. Second, the effect of nanoparticles entering the food chain must be considered and studied.

\section{Nitrification/urease inhibitors}

Nitrification and urease inhibitors increase the efficiency of nutrients applied, generally resulting in higher yields of horticultural and agricultural crops and improved NUE (Trenkel 2007). Nitrification inhibitors are compounds that delay bacterial oxidation of the ammonium ion $\left(\mathrm{NH}_{4}^{+}\right)$by depressing the activities of Nitrosomonas bacteria in the soil over a certain period. They are responsible for the transformation of ammonium into nitrite $\left(\mathrm{NO}_{2}^{-}\right)$, which is further oxidized to nitrate $\left(\mathrm{NO}_{3}{ }^{-}\right)$by Nitrobacter and Nitrosolobus bacteria. The objective of using nitrification inhibitors is, therefore, to control the leaching of nitrate by keeping $\mathrm{N}$ in the ammonium form for longer, to prevent denitrification of nitrate- $\mathrm{N}$ and increase the efficiency of N applied (Sahrawat 1989; Watson et al. 1994; Grant, Jia et al. 1996; Trenkel 1997). The most widely used nitrification inhibitors are 2-chloro-6trichloromethylpyridine (N-serve), 2-amino-4-chloro-6-methyl pyrimidine (AM), dicyan diamide (DCD) and sulfathiazole (ST). For further details on the nitrification and urease inhibitors, readers are referred to reviews by Sahrawat (1989), Subbarao et al. (2006) and Trenkel (1997). Several studies with nitrapyrin, DCD and 3,4dimethylpyrazolephosphate (DMPP) nitrification inhibitors on winter wheat, corn, rice, grain sorghum, potato, sugar beet and cotton have demonstrated that nitrification inhibitors suppress nitrification, improve $\mathrm{N}$ recovery and increase the economic yields significantly (see review by Prasad and Power 1995). As regards the urease inhibitors, they reduce ammonia volatilization losses, particularly from topdressed agricultural fields, as well as under reduced tillage when urea is used as a source of N (Wang et al. 1991; Wang et al. 1994; Bayrakli and Gezgin 1996). The use of urease inhibitors to reduce $\mathrm{NH}_{3}$ volatilization from urea hydrolysis has been considered one effective strategy to increase the NUE of urea-based N products, and more than 14,000 compounds or mixtures of compounds with a wide range of characteristics have been tested (Kiss and Simihaian 2002). Furthermore, urease inhibitors reduce seedling damage when seed-placed levels of urea or urea-containing fertilizers are too high (Grant, Ferguson et al. 1996; Xiaobin et al. 1994). Urease inhibitors prevent or depress over a certain period the transformation of amide- $\mathrm{N}$ in urea to ammonium hydroxide and ammonium. This is achieved by urease inhibitors through suppression of the activities of the enzyme urease, which is responsible for the enzymatic hydrolysis of urea. Urease inhibitors include a large number of organic compounds such as xanthates, hydroxamic acids, heterocyclic sulfur 
compounds, polyhydric phenols and quinines, phosphoro diamidates, phenyl phosphorodiamidate (PPDA) and some inorganic compounds and natural products. Treating urea with Agrotain [formulated and usable version of the urease inhibitor $\mathrm{N}$-(n-butyl)-thiophosphoric triamide or NBTPT] can result in a substantial increase in plant productivity and profitability for farmers (Wade 2009). Chu and Lê (2007) reported that, on average, Agrotain-treated urea increased rice productivity by $27 \%$ as compared with unamended urea in Vietnam. Similarly, Byrnes (1988) reported a $40 \%$ increase in flooded rice productivity due to Agrotain-treated urea compared with unamended urea. Agrotain-treated urea has been found to be effective in reducing the losses of applied $\mathrm{N}$ through $\mathrm{NH}_{3}$ volatilization in field (Wade 2009). Nitrification/urease inhibitors are being used in the USA, Japan and Europe on a limited scale, but it is not possible to use these materials in developing countries like India because of their high cost (Prasad 2008).

It has been reported that the use of some nitrification inhibitors may not only interrupt the activity of some soil bacteria for a certain period, but also result in the killing of soil bacteria. This could be an undesirable interference in the natural agroecosystem (Sturm et al. 1994).

\section{Controlled/slow-release fertilizers (CRF/SRFs)}

An important route for improving NUE is the use of mineral fertilizers, particularly $\mathrm{N}$ fertilizers, which release nutrients according to the plants' requirements, so-called 'intelligent fertilizers', i.e. by the application of slow and controlled-release, or by 'stabilized' $\mathrm{N}$ fertilizers, which preserve the nutrients until plants really require them (Trenkel 2007). Improving nutrient efficiency, and particularly NUE, while reducing environmental hazards by using controlled-release or slow-release fertilizers is an important option (Hauck 1985; Shaviv and Mikkelsen 1993; Peoples et al. 1995; Bockman and Olfs 1998; Shaviv 2001). The greatest consumption and production of CRFs/SRFs is in the USA, Canada, Japan and Europe. A significant proportion of these fertilizers is consumed in nonagricultural markets (e.g. lawn care, golf courses, landscaping) with encouraging signs of increased use for intensively grown crops (vegetables, fruit trees) and rice. Numerous publications deal with the possibility of reducing such losses by using CRF/SRFs (Oertli 1980; Hauck 1985; Shaviv and Mikkelsen 1993; Trenkel 1997; Avasthe 2009; Thind et al. 2010). Recently, the use of slow-release fertilizers has become a new trend to save fertilizer consumption and minimize environmental pollution ( $\mathrm{Gu}$ et al. 2005; Wu and Liu 2008). Controlled or slow-release nitrogenous fertilizers (SRNFs) based on coating with hydrophobic organic polymers are perceived to provide the best control over nutrient release from applied fertilizers (Trenkel 1997). Release from such SRNFs occurs by diffusion (Shaviv et al. 2003). Nutrient release matches the temporal patterns of nutrient uptake by plants and thus significantly reduces environmental pollution due to fertilizer application and improves NUE. Total nutrient requirement, specific periods of peak demand, and preferred chemical forms are specific to each crop and variety. The time pattern of macronutrient uptake by seasonal crops is generally sigmoid in nature (Shoji and Kanno 1994). Therefore, synchronizing nutrient supply with plant demand using a sigmoid pattern of supply will provide optimal nutrition for plant growth and reduce losses by processes competing with nutrient uptake (Oertli 1980; Hauck 1985; Shaviv and Mikkelsen 1993). SRNFs significantly reduce possible nutrient losses, particularly of nitrate $\mathrm{N}$, between application and uptake by the 
plants through gradual nutrient release. They also reduce $\mathrm{N}$ loss via ammonia volatilization. The SRNFs also contribute to a reduction in the emissions of $\mathrm{N}_{2} \mathrm{O}$ (Shaviv and Mikkelsen 1993; Shoji and Kanno 1993, 1994). This substantially decreases the risk of environmental pollution (Koshino 1993; Mikkelsen et al. 1994; Rietze and Seidel 1994; Wang 1996). There are two types of SRNF, namely, coated fertilizers [e.g. sulfur-coated urea, polymer-coated urea, gypsum/rock phosphatecoated urea, lac-coated urea, neem (Azadirachta indica) slurry-coated urea] and inherently slow release materials [e.g. isobutylidene di-urea (IBDU), urea form, urea Z]. Extensive research has been conducted, particularly in India, to demonstrate the slow N-release capacity of urea blended with various neem products. For example, the oil derived from neem seeds (Azadirachta indica L Juss.) contains melicians (generally known as neem bitters) of which Epinimbin, Deacetyl, Salanin and Azadirachtin show dose-dependent nitrification inhibition action (Devkumar and Goswami 1992). Although it has been established that when applied along with urea neem products are capable of enhancing NUE in crops (Singh M and Singh TA 1986), the large-scale use of neem product-blended urea was not possible because the process for large-scale coating of urea with neem products was not available. A simple technique for coating urea with neem cake using kerosene and coal tar (2:1 ratio) solution as an adhesive has been developed and widely tested in India. Recently, the Indian Agricultural Research Institute (IARI) perfected a urea-coating technology employing neem oil emulsion at 0.5 to $1.0 \mathrm{~kg} \mathrm{t}^{-1}$ urea (Suri et al. 2004). Coating of urea prills with neem oil this way is very economical as it costs only $\sim 100$ $\mathrm{Rs} \mathrm{t}^{-1}$ urea. In the Indian context, neem cake-coated urea (NCU) has been found to increase NUE and is a viable technique at the farmer level. It has been found that neem microemulsion-coated urea gave 6-11\% higher rice grain yield compared with uncoated urea (Prasad 2007). At $120 \mathrm{~kg} \mathrm{~N}^{-1}$, neem cake increased recovery efficiency by 12.1 and $37.6 \%$, and agronomic efficiency by 9.9 and $15.8 \%$ compared with $120 \mathrm{~kg} \mathrm{~N}^{-1}$ alone with or without farmyard manure (Avasthe 2009). This corroborates the finding of Mishra (1992), and could be attributed to reducing the leaching loss of nitrate- $\mathrm{N}$ caused by the nitrification inhibitory effect of neem cake. Thind et al. (2010) also noted that NCU gave 9.4, 5.6 and 2.5\% higher grain yield over urea with application of 48, 96 and $120 \mathrm{~kg} \mathrm{~N}^{-1}$, respectively, at Ludhiana, India. The corresponding increase was 3.2, 4.5 and 1.6\% at Gurdaspur, India. These results suggest that the positive impact of nitrification inhibition properties of NCU is more visible in the coarse-textured soils in Ludhiana than in the relatively finetextured soil at Gurdaspur, Punjab, India. They also reported substantially higher recovery and agronomic efficiencies for the NCU as compared with urea, particularly at 48 and $96 \mathrm{~kg} \mathrm{~N} \mathrm{ha}^{-1}$, which further prove the superiority of NCU over urea (Table 8).

Ammonia volatilization constitutes a major $\mathrm{N}$ loss mechanism when urea is the fertilizer (Katyal et al. 1985). One may assume that applying NCU rather than urea should encourage losses via ammonia volatilization because it retards nitrification of $\mathrm{NH}_{4}{ }^{+}$-N. However, if $\mathrm{NCU}$ is either incorporated into soil (basal dose at planting) or applied before the first irrigation event, the losses due to ammonia volatilization can be effectively controlled (Katyal et al. 1985; Thind et al. 2010).

Field evaluation of polymer-coated urea (POCU) indicated that $\mathrm{N}$ losses associated with the nitrification could be substantially reduced, along with a concurrent improvement in N recovery (Shoji and Kanno 1994). Because of the reduced $\mathrm{N}$ losses, the $\mathrm{N}$ requirement from POCU is $\sim 40 \%$ less than the 
Table 8. Fertilizer N-use efficiencies of wheat as influenced by sources and rates of $\mathrm{N}$ at Ludhiana and Gurdaspur, India (data pooled over 3 years).

\begin{tabular}{|c|c|c|c|c|}
\hline \multirow[b]{2}{*}{ Treatments } & \multicolumn{2}{|c|}{ Ludhiana } & \multicolumn{2}{|c|}{ Gurdaspur } \\
\hline & $\begin{array}{l}\text { Agronomic } \\
\text { efficiency } \\
\left(\mathrm{kg} g \text { grain }^{-1} \mathrm{~N}\right) \\
\mathrm{kg}^{-1} \mathrm{~N}\end{array}$ & $\begin{array}{l}\text { Recovery } \\
\text { efficiency } \\
\quad(\%)\end{array}$ & $\begin{array}{l}\text { Agronomic } \\
\text { efficiency } \\
\left(\mathrm{kg}_{\text {grain }}\right. \\
\left.\mathrm{kg}^{-1} \mathrm{~N}\right)\end{array}$ & $\begin{array}{c}\text { Recovery } \\
\text { efficiency }(\%)\end{array}$ \\
\hline \multicolumn{5}{|l|}{ Control } \\
\hline Urea $\left(48 \mathrm{~kg} \mathrm{~N} \mathrm{ha}^{-1}\right)$ & 20.6 & 47.9 & 30.0 & 72.9 \\
\hline Urea $\left(96 \mathrm{~kg} \mathrm{~N} \mathrm{ha}^{-1}\right)$ & 22.0 & 52.0 & 22.4 & 76.0 \\
\hline Urea $\left(120 \mathrm{~kg} \mathrm{~N} \mathrm{ha}^{-1}\right)$ & 19.2 & 53.3 & 21.2 & 80.8 \\
\hline $\mathrm{NCU}\left(48 \mathrm{~kg} \mathrm{~N} \mathrm{ha}^{-1}\right)$ & 25.8 & 70.8 & 32.5 & 91.7 \\
\hline NCU (96 kg N ha $\left.{ }^{-1}\right)$ & 24.2 & 66.7 & 24.5 & 87.5 \\
\hline NCU $\left(120 \mathrm{~kg} \mathrm{~N} \mathrm{ha}^{-1}\right)$ & 20.0 & 60.0 & 21.8 & 83.3 \\
\hline $\begin{array}{l}\text { Urea }\left(120 \mathrm{~kg} \mathrm{~N} \mathrm{ha}^{-1}\right. \\
\text { applied in three doses; } \\
\left.48,48 \text { and } 24 \mathrm{~kg} \mathrm{~N} \mathrm{ha}^{-1}\right)\end{array}$ & 23.9 & 66.7 & 19.3 & 65.0 \\
\hline $\begin{array}{l}\text { NCU }\left(120 \mathrm{~kg} \mathrm{~N} \mathrm{ha}^{-1}\right. \\
\text { applied in three doses; } \\
\left.48,48 \text { and } 24 \mathrm{~kg} \mathrm{~N} \mathrm{ha}^{-1}\right)\end{array}$ & 24.2 & 75.8 & 19.8 & 66.7 \\
\hline $\begin{array}{l}\text { Urea (96 kg N ha-1 } \\
\text { drilled at sowing) }\end{array}$ & 26.7 & 77.1 & 21.6 & 70.8 \\
\hline $\begin{array}{l}\text { NCU (96 kg N ha-1 } \\
\text { drilled at sowing) }\end{array}$ & 29.4 & 79.2 & 22.0 & 67.7 \\
\hline
\end{tabular}

Note: Source: Thind et al. (2010).

recommended levels via normal fertilizers (Balkcom et al. 2003; Zvomuya et al. 2003). Recovery of the basal $\mathrm{N}$ application ranged from $\sim 22 \%$ with conventional broadcast application of ammonium sulfate or urea to $\sim 79 \%$ with co-situs application of POCU (Shoji and Kanno 1994). However, POCU may leave undesired plastic residues in fields (up to $50 \mathrm{~kg} \mathrm{ha}^{-1} \mathrm{y}^{-1}$ ) (Shoji and Kanno 1994).

Compared with the large amount of fertilizers used throughout the world, the total use of slow- and controlled-release fertilizers (SRFs and CRFs) is still very small, despite the fact that use of CRFs has almost doubled over the past decade (Trenkel 1997; Shaviv 2001). Despite the continuing technological developments and commercial availability of several SRFs/CRFs that perform well, their use in practical agriculture is very limited. The main reason for their limited use is their high cost. For example, the cost of POCU is $\sim 4-8$ times that of normal urea (Landels 1991; Detrick 1996). Further, in the case of sulfur-coated fertilizers, there can be rapid release of nutrients in the initial stage compared with conventional fertilizers, causing damage to seedlings or loss of N. Some sulfur-coated fertilizers usually have a thick coating and the nutrient contained in these granules may not be released during the crop-demand period. The application of coated controlledrelease fertilizers may also increase soil acidity. This might be the case if large amounts of sulfur-coated urea are applied, because both sulfur and urea contribute to increased acidity (Trenkel 1997).

Nevertheless, the potential for increased use of CRFs is tremendous in many cases where they have been shown to increase nutrient recovery, sustain high yields and reduce the adverse environmental impacts associated with nutrient loss (Shaviv 2005). 


\section{Laser land leveling}

Improper land leveling is a serious cause of loss of water and nutrients, resulting in low yield and decreased fertilizer use efficiency. Laser leveling, which allows smoothing the land surface to within $\pm 2 \mathrm{~mm}$ of its average elevation using a laserequipped bucket, has a great potential as a precursor to adopting a resource conservation technology (Gill et al. 2008). Because of laser land leveling, a 26.46\% increase in rice yield has been recorded (Pal 2005). Significant improvement in the agronomic efficiency of $\mathrm{N}$ has also been reported in a laser-leveled field in a ricewheat cropping system. The average increase in agronomic efficiency of $\mathrm{N}, \mathrm{P}$ and $\mathrm{K}$ under laser land leveling was 118.2, 130.3 and 130.2\%, respectively, over traditional leveling. Precision land leveling has a tremendous impact (Table 9) on the agronomic efficiency of $\mathrm{N}$ as well as of $\mathrm{P}$ and K (Jat et al. 2004).

\section{Balanced fertilization}

It has been observed that unbalanced NPK ratios diminish the plant use of applied N and decrease the NUE. One of the major factors responsible for the declining growth rate in production, productivity and declining response ratio has been the imbalanced use of NPK, especially following the P and $\mathrm{K}$ decontrol in India in August 1992. Attention to NPK is desirable because $89 \%$ of Indian soils are low to medium in available $\mathrm{N}, 80 \%$ are low to medium in available $\mathrm{P}$ and $50 \%$ are low to medium in available K (Motsara 2002). Therefore, it is essential to apply NPK and other secondary and micronutrients in adequate and balanced amounts. Focus has been given on $\mathrm{N}$ as the main yield-controlling nutrient at the expense of $\mathrm{P}, \mathrm{K}, \mathrm{S}$ and micronutrients (Aulakh and Malhi 2004).

The efficient use of any nutrient depends on the balanced supply of other nutrients, i.e. all nutrients should be available in the right amount and at the right time. The 'Law of the Minimum' emphasizes balanced nutrition (Claupein 1993; Lægrid et al. 1999), a good example of which was presented by Johnston et al. (2001) and the results are presented in Table 10. At adequate levels of extractable (by Olsen's method) soil $\mathrm{P}\left(>19 \mathrm{mg} \mathrm{kg}^{-1}\right)$, the optimum $\mathrm{N}$ application rate for winter wheat yields of $>10 \mathrm{t} \mathrm{ha}^{-1}$ is $160 \mathrm{~kg} \mathrm{ha}^{-1}$ in this experiment; at insufficient levels of extractable soil $\mathrm{P}$, the yield and the $\mathrm{N}$ optimum declines, and any $\mathrm{N}$ applied above the optimum is a risk of loss to the environment as well as being a waste of money. A similar interaction with implications for $\mathrm{N}$ loss has also been noted with respect to $\mathrm{S}$ supply to grassland (Brown et al. 2000).

Table 9. Agronomic efficiency $\left(\mathrm{kg} \mathrm{kg}^{-1}\right)$ of $\mathrm{N}(\mathrm{AE}-\mathrm{N}), \mathrm{P}(\mathrm{AE}-\mathrm{P})$ and $\mathrm{K}(\mathrm{AE}-\mathrm{K})$ under different land leveling systems in rice.

\begin{tabular}{lcccccccc}
\hline & \multicolumn{3}{c}{ AE-N } & & \multicolumn{2}{c}{ AE-P } & & \multicolumn{2}{c}{ AE-K } \\
\cline { 2 - 3 } \cline { 8 - 9 } Treatments & 2003 & 2004 & & 2003 & 2004 & & 2003 & 2004 \\
\hline LL+NPK & 18.75 & 20.00 & & 86.54 & 92.31 & & 56.25 & 60.00 \\
TL+NPK & 7.67 & 9.17 & & 35.38 & 42.31 & & 23.00 & 27.50 \\
TL+NPK & - & - & & - & - & & - & - \\
\hline
\end{tabular}

Note: LL, laser leveling; TL, traditional leveling. \# NPK (control). ${ }^{*} \mathrm{~N}$ at $120 \mathrm{~kg} \mathrm{ha}^{-1}, \mathrm{P}$ at $26 \mathrm{~kg} \mathrm{ha}^{-1}$ and $\mathrm{K}$ at $40 \mathrm{~kg} \mathrm{ha}^{-1}$. Source: Jat et al. (2004). 
Nutrient interactions can also be synergistic, i.e. the increase in yield and NUE are multiplicative, not just additive. Aulakh and Malhi (2004) described the synergistic response to $\mathrm{N}$ and $\mathrm{P}$ as being $13-89 \%$ of the response to $\mathrm{N}+\mathrm{P}$, depending on the yield potential, general level of soil fertility and nutrient application rates. Agronomic efficiency of $\mathrm{N}$ can be greatly increased when adequate $\mathrm{P}$ and $\mathrm{K}$ is applied along with $\mathrm{N}$ (Table 11).

\section{Integrated nitrogen management (INIM)}

Integrated nitrogen management (INIM) refers to the combined use of fertilizer $\mathrm{N}$ and organic N, which includes $\mathrm{N}$ fixed by legumes and other organisms (Azotobacter, Azospirillum, blue-green algae, Azolla etc.) and N supplied by organic manures such as farmyard manure, compost, vermicompost, crop residues and animal refuse. INIM has received considerable attention in recent years for sustaining soil productivity. The use of biofertilizers is particularly important from the eco-safety point of view and to reduce the cost of cultivation. Avasthe (2009) reported that agronomic efficiency and production efficiency decreased with increase in $\mathrm{N}$ level from 80 to $160 \mathrm{~kg} \mathrm{~N}^{-1}$, and the efficiency was higher when mineral $\mathrm{N}$ use was integrated with farmyard manure. The highest values of agronomic efficiency and production efficiency were observed when $80 \mathrm{~kg} \mathrm{~N}^{-1}$ was applied along with $2.5 \mathrm{t}$ farmyard manure ha ${ }^{-1}$. Conjunctive application of urea + farmyard manure

Table 10. Yield of winter wheat $\left(\mathrm{t} \mathrm{ha}^{-1}\right)$ under four rates of applied $\mathrm{N}$ in soils at four levels of available P (measured by Olsen's method) in the soil.

\begin{tabular}{llllr}
\hline & \multicolumn{4}{c}{$\mathrm{N}$ applied $\left(\mathrm{kg} \mathrm{ha}^{-1}\right)$} \\
\cline { 2 - 5 } Available $\mathrm{P}\left(\mathrm{mg} \mathrm{kg}^{-1}\right)$ & 80 & 120 & 160 & 200 \\
\hline 30.4 & 9.32 & 9.64 & $\underline{10.12}$ & 10.25 \\
19.0 & 9.37 & 9.83 & $\underline{10.25}$ & 10.30 \\
10.3 & 8.46 & 9.14 & 7.10 & 9.34 \\
5.0 & $\underline{7.75}$ & 7.88 & 7.85 & 8.08 \\
\hline
\end{tabular}

Note: Values underlined are the optimum $\mathrm{N}$ rates. Adapted from Johnston et al. (2001).

Table 11. Effects of balanced NPK fertilizers on the agronomic efficiency of nitrogen (AEN).

\begin{tabular}{lccccc}
\hline & & & & & \multicolumn{2}{c}{$\begin{array}{c}\text { Increase in } \\
\text { AEN due to } \\
\text { Crop }\end{array}$} & $\begin{array}{c}\text { Control yield } \\
\left(\mathrm{kg} \mathrm{ha}^{-1}\right)\end{array}$ & $\begin{array}{c}\text { N applied } \\
\left(\mathrm{kg} \mathrm{ha}^{-1}\right)\end{array}$ & $\begin{array}{c}\mathrm{N}^{-1} \text { alone } \\
\text { balanced NPK } \\
\text { fertilizers over } \\
\mathrm{N} \text { alone }(\%)\end{array}$ \\
\hline Rice & 2740 & 40 & 13.5 & 27.0 & 100 \\
Wheat & 3030 & 40 & 10.5 & 81.0 & 671 \\
Pearlmillet & 1450 & 40 & 10.8 & 20.0 & 85 \\
Maize & 1050 & 40 & 4.7 & 15.0 & 219 \\
Sorghum & 1670 & 40 & 19.5 & 39.0 & 100 \\
Sugar cane & 1270 & 40 & 5.3 & 12.30 & 126 \\
& 42200 & 150 & 78.7 & 227.7 & 189 \\
\hline
\end{tabular}

Note: Adapted from Prasad (1996). 
increased the agronomic efficiency by 5.4-14.8\%. Dadarwal et al. (2009) reported that the application of $75 \%$ recommended dose of fertilizers (RDF) $+2.5 \mathrm{t}$ vermicompost $\mathrm{ha}^{-1}+$ biofertilizers to maize significantly improved plant height, dry matter accumulation, dehusked cob yield, green fodder yield and available NPK in the soil after the harvest of crop over the 150\% RDF (RDF values were 120:40: $30 \mathrm{~kg} \mathrm{ha}^{-1}$ of NPK). An $\sim 29.0 \%$ increase in dehusked cob yield was recorded with $75 \%$ NPK $+2.5 \mathrm{t}$ vermicompost $\mathrm{ha}^{-1}+$ biofertilizers over $150 \%$ NPK through mineral fertilizers. These results can be attributed to the combined effect of fertilizer vermicompost and biofertilizers, in particular, vermicompost has a favorable influence on soil condition and synchronized release of plant nutrients throughout the crop growth period, which had positive effect on the source-sink relationship and ultimately on economic yield.

Besides, other management practices like time and method of $\mathrm{N}$ application, the use of different urea forms (e.g. urea super granules), mud balls, foliar spray, nutrient budgets or audits should all be followed to supplement the above-discussed approaches to improve the overall NUE. Top-dressing of $\mathrm{N}$ at later stage of the wheat crop proved most effective in increasing grain protein concentration, yield and fertilizer use efficiency (Krishna Kumari et al. 2000). Split application of $N$ to wheat showed a marked advantage for grain and total $\mathrm{N}$ uptake, and resulted in enhancing yield (Geleto et al. 1996). According to Anupreet Kaur et al. (2010), N applied in four splits (foliar spray) increased $\mathrm{N}$ recovery under all dates of sowing over the treatment in which $\mathrm{N}$ was soil applied in two or three splits in wheat. To get the highest NUE, $\mathrm{N}$ may be applied in three splits $\left(68 \mathrm{~kg} \mathrm{~N}^{-1}\right.$ at sowing $+75 \mathrm{~kg} \mathrm{~N}$ $\mathrm{ha}^{-1}$ at first irrigation $+7 \mathrm{~kg} \mathrm{~N}^{-1}$ (3\% urea spray) at the anthesis growth stage of wheat. An adequate supply of $\mathrm{N}$ during the later crop growth stages delays the synthesis of abscisic acid, promotes cytokinin activity and causes higher chlorophyll retention and thereby higher photosynthesis activity in leaves for the supply of photosynthates to grains (Sarkar et al. 2007). Maximum recovery efficiency and agronomic efficiency were observed in rice for $1 / 4 \mathrm{~N}$ at 10 days after transplanting + $1 / 4$ at maximum tillering $+1 / 2$ at panicle initiation, which was $11.1-97.1 \%$ and $9.0-$ $180.1 \%$ higher than under other schedules (Avasthe 2009). Kumar et al. (1998) reported that NUE was greater in optimum and timely sown crop as compared with late sown crop. Kundu and Sarkar (2009) reported that spraying of either of $\mathrm{KNO}_{3}$ or $\mathrm{Ca}\left(\mathrm{NO}_{3}\right)_{2}$ during the $50 \%$ flowering stage in rainfed lowland rice proved to be more effective. Foliar application of $0.406 \% \mathrm{Ca}\left(\mathrm{NO}_{3}\right)_{2}$ during the $50 \%$ flowering stage gave a $111.7 \%$ higher yield over the lowest recorded under water spray during the milk stage. Foliar spray of $0.50 \% \mathrm{KNO}_{3}$ and $\mathrm{Ca}\left(\mathrm{NO}_{3}\right)_{2}$ increased the uptake of $\mathrm{N}$ over the water spray treatment. However, foliar fertilization of $0.406 \% \mathrm{Ca}\left(\mathrm{NO}_{3}\right)_{2}$ showed higher uptake of $\mathrm{N}$ over the $0.50 \% \mathrm{KNO}_{3}$ spray treatment, possibly because of a significant role of $\mathrm{Ca}^{2+}$ in more rational utilization of soil $\mathrm{N}$ and active assimilation of $\mathrm{NO}_{3}^{-}$in roots and leaves. Similarly, ion-exchange resin capsules can be helpful in effective $\mathrm{N}$ scheduling through precise pre-season soil test to assess the soil NPK supply (Dobermann et al. 1998).

\section{Conclusions}

Low NUE is one among several major factors responsible for the huge yield gap in most field crops. In addition to economic loss due to low NUE and wastage, N leakages into the environment are the major causes of concern. To maintain and 
even increase the efficiency of $\mathrm{N}$ use, more precise and diverse $\mathrm{N}$ management strategies are needed. For precise $\mathrm{N}$ management, spatial variability in $\mathrm{N}$ application, remote sensing or canopy $\mathrm{N}$ status sensors to quantify real-time crop $\mathrm{N}$ status are essential to adopt. These apart, prediction of soil $\mathrm{N}$ supply capacity, maintaining harmony between supply and crop demand through the adoption of balanced fertilization, integrated N management, the use of SRNF and nitrification/ urease inhibitors, optimizing the time and method of fertilizer application, changing the fertilizer form to suit need, are all helpful in achieving the goal of higher NUE and sustainability.

\section{References}

Adhikari C, Bronson KF, Panuallah GM, Regmi AP, Saha PK, Dobermann A, Olk DC, Hobbs PR, Pasuquin E. 1999. On-farm N supply and N nutrition in the rice-wheat system of Nepal and Bangladesh. Field Crops Res. 64:273-286.

Ahlawat RPS. 2008. Reorientation of agronomic research. In: Sharma et al., editors. Souvenir, National Symposium on New Paradigms in Agronomic Research; 2008 Nov 19-21; New Delhi, India: Navsari Agricultural University, Navsari. p. 1-9.

Angus JF, St. Groth CFD, Tasic RC. 1990. Between-farm variability in yield responses to inputs of fertilizers and herbicide applied to rainfed lowland rice in the Philippines. Agr Ecosyst Environ. 30:219-234.

Annual Report. 2006-07. Project Directorate for Cropping System Research, Modipuram, Meerut. p. 57-62.

Anupreet Kaur, Pannu RK, Buttar GS. 2010. Impact of nitrogen application on the performance of wheat (Triticum aetivum) and nitrogen use efficiency under different dates of sowing. Indian J Agron. 55(1):40-45.

Arora RP, Sachdev MS, Sud YK, Luthra VK, Subbiah BV. 1980. Fate of fertilizer nitrogen in a multiple cropping system. In: Soil fertilizer as fertilizer or pollutant. Vienna (Austria): International Atomic Energy Agency. p. 3-22.

Aulakh MS, Bijay-Singh. 1997. Nitrogen losses and N-use efficiency in porous soils. Nutr Cycl Agroecosyst. 47:197-212.

Aulakh MS, Malhi SS. 2004. Fertiliser nitrogen use efficiency as influenced by interactions with other nutrients. In: Mosier AR, Syers JK, Freney JR, editors. Agriculture and the nitrogen cycle. Assessing the impacts of fertilizer use on food production and the environment. SCOPE 65. Washington (DC): Island Press. p. 181-191.

Avasthe R. 2009. Nitrogen management in transplanted rice (Oryza sativa) in mid hill acidic soils of Sikkim Himalayas. Indian J Agron. 54(1):47-51.

Balasubramanian V, Morales AC, Cruz RT, Abdulrachman S. 1999. On-farm adaptation of knowledge-intensive nitrogen management technologies for rice systems. Nutr Cycl Agroecosyst. 53:93-101.

Balasubramanian V, Morales AC, Cruz RT, Thiyagarajan TM, Nagarajan R, Babu M, Abdulrachman S, Hai LH. 2000. Adaptation of the chlorophyll meter (SPAD) technology for realtime $\mathrm{N}$ management in rice: a review. Int Rice Res Notes. 25(1):4-8.

Balkcom K, Blackmer AM, Hansen DJ, Morris TF, Mallarino AP. 2003. Testing soils and cornstalks to evaluate nitrogen management on the watershed scale. J Environ Qual. 32:1015-1024.

Bayrakli F, Gezgin S. 1996. Controlling ammonia volatilization from urea surface applied to sugar beet on a calcareous soil. Commun Soil Sci Plant Anal. 27(9/10):2443-2451.

Bijay-Singh. 2008. Crop demand-driven site-specific nitrogen applications in rice (Oryza sativa) and wheat (Triticum aestivum): some recent advances. Indian J Agron. 53(3):157166.

Bijay-Singh, Bronson KF, Yadvinder-Singh, Khera TS, Pasuquin E. 2001. Nitrogen-15 balance as affected by rice straw management in a rice-wheat rotation in northwest India. Nutr Cycl Agroecosyst. 59:227-237.

Bijay-Singh, Singh Y, Ladha JK, Bronson KF, Balasubramanian V, Singh J, Khind CS. 2002. Chlorophyll meter- and leaf color chart-based nitrogen management for rice and wheat in northwestern India. Agron J. 94:821-829. 
Bijay-Singh, Yadvinder-Singh. 2003. Environmental implications of nutrient use and crop management in rice-wheat cropping system. In: Yadvinder-Singh et al., editors. Nutrient management for sustainable rice-wheat cropping system. New Delhi (India): National Agricultural Technology Project, Indian Council for Agricultural Research and Ludhiana (India): Punjab Agricultural University. p. 398-412.

Bijay-Singh, Yadvinder-Singh. 2008. Reactive nitrogen in Indian agriculture: inputs, use efficiency and leakages. Curr Sci. 94:1382-1393.

Bockman OC, Olfs HW. 1998. Fertilizers, agronomy and $\mathrm{N}_{2} \mathrm{O}$. Nutr Cycl Agroecosyst. $52: 165-170$.

Boote KJ, Hoogenboom G, Jones JW, Ingram KT. 2009. Modeling nitrogen fixation and its relationship to nitrogen uptake in the CROPGRO model. In: Liwang MA, Ahuja LR, Bruulsema T, editors. Quantifying and understanding plant nitrogen uptake for systems modeling. Boca Raton (FL): CRC Press. p. 13-46.

Bradbury NJ, Whitmore AP, Hart PBS, Jenkinson DS. 1993. Modelling the fate of nitrogen in crop and soil in the years following application of ${ }^{15} \mathrm{~N}$-labelled fertilizer to winter wheat. J Agr Sci. 121:363-379.

Brown L, Scholefield D, Jewkes EC, Lockyer DR, del Prado A. 2005. NGAUGE: a decision-support system to optimise $\mathrm{N}$ fertilisation of British grassland for economic and/or environmental goals. Agr Ecosyst Environ. 109:20-39. doi:10.1016/ j.agee.2005.02.021

Brown L, Scholefield D, Jewkes EC, Preedy N, Wadge KJ, Butler MR. 2000. The effect of sulphur application on the efficiency of nitrogen use in two contrasting grassland soils. J Agr Sci. 135:131-138.

Buresh RJ, Witt C, Ramanathan S, Mishra B, Chandrasekaran B, Rajendran R. 2005. Sitespecific nutrient management - managing N, P, and K for rice. Fertil. News 50(3):25-28$31-37$

Byrnes BH. 1988. The degradation of the urease inhibitor phenyl phosphorodiamidate in soil systems and the performance of $N$-(n-butyl) thiophosphoric triamide in flooded rice cultural [PhD thesis]. [Weihenstephan (Germany)]: Technical University of Munich.

Cassman KG, Dobermann A, Walters D. 2002. Agroecosystems, nitrogen-use efficiency, and nitrogen management. Ambio. 31:132-140.

Chu HV, Lê BH. 2007. Study on the effects of Agrotain coated urea on high yielding rice in the Mekong delta of Vietnam. Codo, Cantho, Vietnam: Cuu Long Delta Rice Research Institute. p. 22.

Claupein W. 1993. Nitrogen fertilization and chemical plant protection in a long-term field experiment and the yield response laws of Liebig, Liebscher, Wollny and Mitscherlich. J Agron Crop Sci. 171:102-113.

Cotae V, Creanga I. 2005. LHC II system sensitivity to magnetic fluids. J Magn Magn Mater. 289:459-462.

Dadarwal RS, Jain NK, Singh D. 2009. Integrated nutrient management in baby corn (Zea mays). Indian J Agr Sci. 79:1023-1025.

Detrick J. 1996. RLC membrane encapsulated fertilizer technology can deliver high yield value benefits for agriculture. Proceedings of Great Plains Soil Fertility Conference; J. Havlin (ed.) 1996; Denver, CO: Kansas State University Press.

Devkumar C, Goswami BK. 1992. Neematicidal principles from neem isolation and bioassay of some meliacins. J Pestic Resid. 4:79-84.

Dinnes DL, Karlen DL, Jaynes DB, Kaspar TC, Hatfield JL, Colvin TS, Cambardella CA. 2002. Nitrogen management strategies to reduce nitrate leaching in tile drained midwesten soils. Agron J. 94:153-171.

Dobermann A, Cassman KG, Mamaril CP, Sheehy JE. 1998. Management of phosphorus, potassium, and sulfur in intensive, irrigated lowland rice. Field Crops Res. 56:113-138.

Dobermann A, Cassman KG, Peng S, Tan PS, Phung CV, Santa Cruz PC, Bajita JB, Adviento MAA, Olk DC. 1996. Precision nutrient management in intensive irrigated rice systems. In: Proceedings of the International Symposium on Maximizing Sustainable Rice Yields Through Improved Soil and Environmental Management; Khon Kaen, Bangkok, Thailand: Department of Agriculture, Soil and Fertilizer Society of Thailand, Department of Land Development, ISSS, Bangkok. p. 133-154. 
Dobermann A, Witt C, Dawe D, Abdulrachman S, Gines HC, Nagarajan R, Satawathananont S, Son TT, Tan PS, Wang GH, Chien NV, Thoa VT, Phung CV, Stalin P, Muthukrishnan P, Ravi V, Babu M, Chatuporn S, Sookthongsa J, Sun Q, Fu R, Simbahan GC, Adviento MAA. 2002. Site-specific nutrient management for intensive rice cropping systems in Asia. Field Crops Res. 74:37-66.

Dwivedi BS, Shukla AK, Singh VK, Yadav RL. 2001. Results of participatory diagnosis of constraints and opportunities (PDCO) based trials from the state of Uttar Pradesh. In: Subba Rao A, Srivastava, editors. Development of farmers' resource-based integrated plant nutrient supply systems: experience of a FAO-ICAR-IFFCO collaborative project and AICRP on soil test crop response correlation. Bhopal (India): IISS. p. 50-75.

Erisman JW, Sutton MA, Galloway J, Klimont Z, Winiwarter W. 2008. How a century of ammonia synthesis changed the world. Nat Geosci. 1:636-639.

Evenson RE, Gollin D. 2003. Assessing the impact of the green revolution, 1960 to 2000. Science. 300:758-762.

FAO. 2001. Global estimates of gaseous emissions of $\mathrm{NH}_{3}, \mathrm{NO}$ and $\mathrm{N}_{2} \mathrm{O}$ from agricultural land. Rome: International Fertilizer Industry Association, Food and Agricultural Organization.

Follett RH, RF Follett, Halvorson AD. 1992. Use of a chlorophyll meter to evaluate the nitrogen status of dryland winter wheat. Commun Soil Sci Plant Anal. 23:687-697.

Fox RH, Roth GW, Iversen KV, Piekielek WP. 1989. Soil and tissue nitrate tests compared for predicting soil nitrogen availability to corn. Agron J. 81:971-974.

Furuya S. 1987. Growth diagnosis of rice plants by means of leaf color. Jpn Agr Res Q. 20:147-153.

Geleto T, Taner DG, Tekalign M, Getinet G. 1996. Response of rainfed bread and durum wheat to source, level and timing of nitrogen fertilizer on two Ethiopian vertisols. II. N uptake, recovery and efficiency. Fertil Res. 44:195-204.

Gill MS, Pal SS, Ahlawat IPS. 2008. Approaches for sustainability of rice (Oryza sativa)wheat (Triticum aestivum) cropping system in Indo-Gangetic plains of India - a review. Indian J Agron. 53(2):81-96.

Gill MS, Shukla AK, Singh MP, Tomar OK, Raj Kumar, Majumdar K, Tiwari KN. 2009. Evaluation of nutrient management options for yield, economics, and nutrient use efficiency. Better Crops. III:12-15.

Goodlass G, Rahn C, Shepherd MA, Chalmers AG, Seeney FM. 1997. The nitrogen requirement of vegetables: comparisons of yield response models and recommendation systems. J Hortic Sci. 72:239-254.

Goswami NN, Prasad R, Sarkar MC, Singh S. 1988. Studies on the effect of green manuring and nitrogen economy in a rice-wheat rotation using ${ }^{15} \mathrm{~N}$ technique. J Agr Sci Camb. 111:413-417.

Grant CA, Ferguson R, Lamond R, Schlegel A, Thomas W. 1996. Use of urease inhibitors in the Great Plains. In: Proceedings Great Plains Soil Fertility Conference; J. Havlin (ed.) 1996; Denver, CO: Kansas State University Press.

Grant CA, Jia S, Brown KR, Baily LD. 1996. Volatile losses of $\mathrm{NH}_{3}$ from surface-applied urea and urea ammonium nitrate with and without the urease inhibitors NBPT or ammonium thiosulphate. Can J Soil Sci. 76:417-419.

Gu MY, Liu MZ, Zhan FL, Wu L. 2005. Preparation and properties of a slow-release membrane-encapsulated urea fertilizer with superabsorbent and moisture preservation. Ind Eng Chem Res. 44:4206-4211. doi: 10.1021/ie0489406

Gupta R. 2006. Crop canopy sensors for efficient nitrogen management in the Indo-Gangetic plains. Progress Report (11-1-2004 to 10-31-2006). Mexico: The Rice-Wheat Consortium, New Delhi International Maize and Wheat Improvement Center (CIMMYT). http://www.nue.okstate.edu/GreenSeeker/GS\%20-Full\%20TechReport-\%20\%20Dec\%2014-06. pdf

Hach CV, Tan PS. 2007. Study on site-specific nutrient management for high-yielding rice in the Mekong delta. Omonrice. 15:144-152.

Hauck RD. 1985. Slow release and bio-inhibitor-amended nitrogen fertilisers. In: Engelstad OP, editor. Fertiliser technology and use. 3rd ed. Madison (WI): SSSA. p. 293-322.

Hong SD, Fox RH, Piekielek WP. 1990. Field evaluation of several chemical indexes of soil nitrogen availability. Plant Soil. 123:83-88.

Howarth RW, Boyer EW, Pabich WJ, Gallonway JM. 2002. Nitrogen use in the United States from 1961-2000 and potential and future trends. Ambio. 31:88-96. 
Hussain F, Bronson KF, Yadvinder-Singh, Bijay-Singh, Peng S. 2000. Use of chlorophyll meter sufficiency indices for nitrogen management of irrigated rice in Asia. Agron J. 92:875-879.

IRRI-CREMNET. 1998. IRRI-Crop and Resource Management Network. Progress report for 1997. Manila (Philippines): IRRI.

Jansson SL, Persson J. 1982. Mineralization and immobilization of soil nitrogen. In: Stevenson FJ, editor. Nitrogen in agricultural soils agronomy monograph 22. Madison (WI): ASA, CSSA, SSSA. p. 229-252.

Janzen HH, Beauchemin KA, Bruinsma Y, Campbell CA, Desjardins RL, Ellert BH, Smith EG. 2003. The fate of nitrogen in agroecosystems: an illustration using Canadian estimates. Nutr Cycl Agroecosyst. 67:85-102.

Jarvis SC. 1996. Future trends in nitrogen research. Plant Soil. 181:47-56.

Jat ML, Pal SS, Subha Rao AVM, Sirohi K, Sharma SK, Gupta RK. 2004. Laser land leveling the precursor technology for resource conservation in irrigated eco-system of India. In: Proceedings of National Conference on Conservation Agriculture: Conserving ResourcesEnhancing Productivity; 2004 Sep 22-23; New Delhi, India: NASC Complex Pusa. p. 9-10.

John PS, Buresh RJ, Prasad R, Pandey RK. 1989. Nitrogen gas flux $\left(\mathrm{N}_{2}+\mathrm{N}_{2} \mathrm{O}\right)$ flux from urea applied to lowlnd rice as affected by green manure. Plant Soil. 119:7-13.

Johnston AE, Goulding KWT, Poulton PR, Chalmers A. 2001. Reducing fertiliser inputs: endangering arable soil fertility? In: Proceedings 487. York (UK): International Fertiliser Society. p. 44.

Joseph T, Morrison M. 2006. Nanotechnology in agriculture and food. . www.nanoforum.org.

Justes E, Meynard JM, Mary B, Plénet D. 1997. Management of N nutrition: diagnosis using stem base extract: JUBIL method. In: Lemaire G, editor. Diagnosis of the nitrogen status in crops. Berlin (Germany): Springer-Verlag. p. 163-187.

Katyal JC, Singh B, Vlek PLG, Craswell ET. 1985. Fate and efficiency of nitrogen fertilizer applied to wetland rice. II. Punjab, India. Fertil Res. 6:279-290.

Keeney D. 1997. What goes around comes around - the nitrogen issues cycle. In: Mortwedt JJ, Shaviv A, editors. Third International Dahlia Greidinger Symposium on Fertilization and The Environment; 1997 Apr; Haifa, Israel.

Khurana HS, Phillips SB, Bijay-Singh, Dobermann A, Sidhu AS, Yadvinder-Singh, Peng S. 2007. Performance of site-specific nutrient management for irrigated, transplanted rice in northwest India. Agron J. 99:1436-1447.

Khurana HS, Singh Bijay, Dobermann A, Phillips SB, Sidhu AS, Singh Y. 2008. Site-specific nutrient management performance in a rice-wheat cropping system. Better Crops. 92(4):26-28.

Kiss S, Simihaian M. 2002. Improving efficiency of urea fertilizers by inhibition of soil urease activity. Dordrecht (The Netherlands): Kluwer Academic. p. 417.

Kitchen NR, Goulding KWT. 2001. On-farm technologies and practices to improve nitrogen use efficiency. In: Follett RF, Hatfield JL, editors. Nitrogen in the environment: sources, problems, and management. Amsterdam (The Netherlands): Elsevier. p. 335-369.

Koshino M. 1993. The environmental protection framework concerning fertilizer use in Japan. Tsukuba (Japan): National Institute of Agro-Environmental Sciences, Department of Farm Chemicals.

Krishna Kumari M, Sharma RK, Balloli SS. 2000. Effect of late application of nitrogen on yield and protein content of wheat. Ann Agr Res. 21:288-291.

Krupnik TJ, Six J, Ladha JK, Paine MJ, Van Kessel C. 2004. An assessment of fertilizer nitrogen recovery efficiency by grain crops. In: Mosier AR et al., editors. Agriculture and the nitrogen cycle: assessing the impacts of fertilizer use on food production and the environment. Paris (France): Scientific Committee on Problems of the Environment. p. 193-207.

Kumar S, Bangarwa AS, Singh DP, Phogat SB. 1998. Dry matter accumulation in dwarf wheat varieties under different nitrogen level and sowing dates. Ann Agr Res. 28:151-157.

Kundu Chaity, Sarkar RK. 2009. Effect of foliar application of potassium nitrate and calcium nitrate on performance of rainfed lowland rice (Oryza sativa). Indian J Agron. 54:428-432.

Ladha JK, Pathak H, Krupnik T, Six J, Van Kessel C. 2005. Efficiency of fertilizer nitrogen in cereal production: retrospects and prospects. Adv Agron. 87:85-156.

Ladha JK, Pathak H, Tirol-Padre A, Dawe D, Gupta RK. 2003. Productivity trends in intensive rice-wheat cropping systems in Asia. In: Ladha JK, Hill JE, Duxbury JM, Gupta RK, Buresh $\mathrm{RJ}$, editors. Improving the productivity and sustainability of rice-wheat systems: issues and impacts. ASA Special Publication 65. Madison (WI): ASA, CSSA, SSSA. p. 45-76. 
Lægrid M, Bøckman OC, Kaarstad O. 1999. Agriculture, fertilizers and the environment. Wallingford (UK): CAB International.

Landels SP. 1991. U.S. markets for controlled-release fertilizers: Present size and value, projected demand, trends, and opportunities for new CRF products. In: Scheib RM, editor. Controlled Release Fertilizer Workshop, TVA, 1991. Muscle Shoals (AL): Tennessee Valley Authority. p. 87-101.

Lemaire G, Gastal F. 1997. N uptake and distribution in plant canopies. In: Lemaire G, editor. Diagnosis of the nitrogen status in crops. Berlin (Germany): Springer-Verlag. p. 3-43.

Magdoff FR, Jokela WE, Fox RH, Griffin GF. 1990. A soil test for nitrogen availability in the northeastern United States. Commun Soil Sci Plant Anal. 21:1103-1115.

Marschner H. 1997. Mineral nutrition of higher plants. 2nd ed. Orlando (FL): Harcourt Brace.

Mason MG. 1992. Effect of nitrogen source and soil type on inorganic nitrogen concentrations and availability in field trials with wheat. Aust J Exp Agr. 32:175-181.

McGill WB, Campbell CA, Dormaar JF, Paul EA, Anderson DW. 1981. Soil organic matter loss. In: Agriculture Land: Our Disappearing Heritage. Proceedings of the Annual Alberta Soil Science Workshop; 1981 Feb 24-25; Alberta Soil and Feed Testing Lab., Edmonton. p. $72-133$.

Meelu OP, Gupta RK. 1980. Time of fertilizer N application in rice culture. Int Rice Res Newsl. 5(3):20-21.

Mikkelsen RL, Williams HM, Behel AD, Jr. 1994. Nitrogen leaching and plant uptake from controlled-release fertilizers. Fertil Res. 37:43-50.

Mishra MM. 1992. Enrichment of organic manures with fertilizers. In: Tandon HLS, editor. Non-traditional sectors for fertilizer use. New Delhi (India): Fertilizer Development Corporation Organization. p. 48-60.

Moser A, Schimel D, Valentine D, Bronson K, Parton W. 1991. Methane and nitrous oxide fluxes in native fertilized and cultivated grassland. Nature 350, March.

Motsara MR. 2002. Available nitrogen, phosphorus and potassium status of Indian soils as depicted by soil fertility maps. Fertil Newsl. 47(8):15-21.

Oertli JJ. 1980. Controlled-release fertilisers. Fertil Res. 1:103-123.

Pal SS. 2005. Precision farming - final project report under NATP. Modipuram (India): Project Directorate for Copping Systems Research.

Pathak H, Li C, Wassman R, Ladha JK. 2006. Simulation of nitrogen balance in the ricewheat systems of the Indo-Gangetic plains. Soil Sci Soc Am J. 70:1612-1622.

Pathak H, Singh UK, Patra AK, Kalra N. 2004. Fertilizer use efficiency to improve environmental quality. Fertil News. 49(4):95-105.

Pathak H, Yadvinder-Singh, Bijay-Singh. 2003. Site-specific nutrient management for improving the productivity of rice-wheat cropping system. In: Yadvinder-Singh et al., editors. Nutrient management for sustainable rice-wheat cropping system. New Delhi (India): National Agricultural Technology Project, Indian Council for Agricultural Research and Ludhiana (India): Punjab Agricultural University. p. 79-98.

Pavel A, Creanga DE. 2005. Chromosomal aberrations in plants under magnetic fluid influence. J Magn Magn Mater. 289:469-472.

Pavel A, Trifan M, Bara II, Creanga DE, Cotae C. 1999. Accumulation dynamics and some cytogenetical tests at Chelidonium majus and Papaver somniferum callus under the magnetic liquid effect. J Magn Magn Mater. 201:443-445.

Peng S, Cassman KG. 1998. Upper thresholds of nitrogen uptake rates and associated nitrogen fertilizer efficiencies in irrigated rice. Agron J. 90:178-185.

Peng SB, Buresh RJ, Huang JL, Yang JC, Zou YB, Zhong XH, Wang GH. 2005. Overapplication of nitrogen fertilizer in intensive rice system in China. In: Li CJ, Zhang FS, Dobermann A, Lambers H, Li XL, Marschner P, Maene L, McGrath S, Oenema O, Peng SB, Rengel Z, Shen QR, Welch R, von Wiren N, Yan XL, Zhu YG, editors. Plant nutrition for food and security, human health and environment protection. XVIPNC 2005, Beijing, China. Beijing (China): Tsinghua University Press. p. 62-63.

Peoples MB, Freney JR, Moiser AR. 1995. Minimizing gaseous losses of nitrogen. In: Bacon PE, editor. Nitrogen fertilization in the environment. New York: Marcel Dekker. p. 565-601.

Peterson TA, Blackmer TM, Francis DD, Schepers JS. 1993. Using a chlorophyll meter to improve N management. Nebguide G93-1171A. Linclon (NE): Coop. Ext. Serv., Univ. of Nebraska. 
Pierce FJ, Nowak P. 1999. Aspects of precision agriculture. Adv Agron. 67:1-85.

Prasad R. 2005. Rice-wheat cropping systems. Adv Agron. 86:255-323.

Prasad R. 2007. Nitrogen. In: Prasad R, editor. Crop nutrition - principles and practices. New Dehli (India): New Vishal. p. 27-78.

Prasad R. 2008. Fertilizer research and use in India - present status, future needs, problems and policy issues. In: Sharma AR et al., editors. Souvenir, National Symposium on New Paradigms in Agronomic Research; 2008 Nov 19-21; Navsari, India: Indian Society Agronomy. p. 10-19.

Prasad R, Power JF. 1995. Nitrification inhibitors for agriculture, health, and the environment. Adv Agron. 54:233-281.

Rietze E, Seidel W. 1994. Vollbevorratung mitumhülltem Langzeitdünger senkt die Nitratauswaschung [An adequate supply of coated slowacting fertilizers reduces nitrate leaching]. Versuchsstation Christinenthal (Germany) Urania Agrochem. Gartenbau Magazin. 3(7):32-33.

Robert PC. 2002. Precision agriculture: a challenge for crop nutrition management. Plant Soil. 247:143-149.

Sahrawat KL. 1980. Nitrification in some tropical soils. Plant Soil. 65:281-286.

Sahrawat KL. 1989. Effects of nitrification inhibitors on nitrogen transformations, other than nitrification, in soils. Adv Agron. 42:279-309.

Sahrawat KL. 2008. Factors affecting nitrification in soils. Commun Soil Sci Plant Anal. 39:1436-1446.

Sarkar RK, Deb N, Parya MK. 2007. Effect of seed treatment and foliar nutrition on growth and productivity of spring sunflower (Helianthus annuus). Indian J Agr Sci. 77(3):191-194.

Scholefield D, Lockyer DR, Whitehead DC, Tyson KC. 1991. A model to predict transformations and losses of nitrogen in UK pastures grazed by beef-cattle. Plant Soil. 132:165-177.

Schröder JJ, Neeteson JJ, Oenema O, Strui PC. 2000. Does the crop or the soil indicate how to save nitrogen in maize production? Reviewing the state of the art. Field Crops Res. 66:151-164.

Scott N, Chen H. 2003. Nanoscale science and engineering for agriculture and food systems. Washington (DC): Cooperative State Research, Education and Extension Service, United States Department of Agriculture.

Shaviv A. 2001. Improvement of fertilizer efficiency - product processing, positioning and application methods. Proc Int Fertil Soc. 469:1-23.

Shaviv A. 2005. Controlled release fertilizers. In: IFA International Workshop on EnhancedEfficiency Fertilizers; 2005 June 28-30; Frankfurt, Germany. http://www.fertilizer.org/ifa/ Home-Page/LIBRARY/Conference-papers/Agriculture-Conferences/2005-IFA-AgricultureWorkshop. Accessed 24 December 2010.

Shaviv A, Mikkelsen RL. 1993. Slow release fertilisers for a safer environment maintaining high agronomic use efficiency. Fertil Res. 35:1-12.

Shaviv A, Raban S, Zeidel E. 2003. Modeling controlled nutrient release from a population of polymer coated fertilizers: statistically based model for diffusion release. Environ Sci Technol. 37:2251-2256.

Shoji S, Kanno H. 1993. Innovation of new agrotechnology using controlled release fertilizers for minimizing the environmental deterioration. In: Proceedings of the Dahlia Greidinger Memorial International Workshop on Controlled/Slow Release Fertilizers; 1993 Mar 7 12; Haifa, Israel: Technion-Israel Institute of Technology.

Shoji S, Kanno H. 1994. Use of polyolefin-coated fertilizers for inceasing fertilizer efficiency and reducing nitrate leaching and nitrous oxide emissions. Rev Fertil Res. 39:147-152.

Shukla AK, Singh VK, Dwivedi BS, Sharma SK, Tiwari KN. 2004. Site-specific nutrient management for maximum economic yield of the rice-wheat cropping system. Better Crops. 88(4):18-21.

Singh I, Srivastava AK, Chandna P, Gupta RK. 2006. Crop sensors for efficient nitrogen management in sugarcane: potential and constraints. Sugar Tech 8(4):299-302. doi: 10.1007/BF02943572

Singh M, Singh TA. 1986. Leaching losses of nitrogen from urea as affected by application of neem-cake. J Indian Soc Soil Sci. 34:766-773. 
Singh VK, Jat ML, Sharma SK. 2005. Rice-wheat information sheet. New Dehli (India): Rice-Wheat Consortium for the Indo-Gangetic Plains. p. 5.

Smil V. 1999. Nitrogen in crop production: an account of global flows. Global Biogeochem Cycl. 13(2):647-662.

Smil V. 2002. Nitrogen and food production: proteins for human diets. Ambio. 31:126-131.

Smith JU, Bradbury NJ, Addiscott TM. 1996. SUNDIAL: a PC-based system for simulating nitrogen dynamics in arable land. Agron J. 88:38-43.

Srivastava HS, Singh RP. 1999. Nitrogen nutrition and plant growth. Oxford: IBH Publishing.

Ssali H. 1990. Initial and residual effects of nitrogen fertilizers on grain yield of maize/bean intercrop grown on a humic nitosol and the fate and efficiency of the applied nitrogen. Fertil Res. 23:63-72.

Stalin P, Dobermann A, Cassman KG, Thiyagarajan TM, Ten Berge HFM. 1996. Nitrogen supplying capacity of lowland rice soil of southern India. Commun Soil Sci Plant Anal. 27:2851-2874.

Strong WM, Cooper JE. 1992. Application of anhydrous ammonia or urea during the fallow period for winter cereals on the Darling Downs, Queensland. I. Effect of time of application on soil mineral N at sowing. Aust J Soil Res. 30:695-709.

Sturm H, Buchner A, Zerulla W. 1994. Gezielter düngen. Integriert - wirtschaftlich umweltgerecht [Directed fertilizer use - integrated - economically - environmentally sound]. Frankfurt am Main (Germany): Verlags Union Agrar, DLG-Verlags.

Subbarao GV, Ito O, Sahrawat KL, Berry WL, Nakahara K, Ishikawa T, Watanabe T, Suenaga K, Rondon M, Rao IM. 2006. Scope and strategies for regulation of nitrification in agricultural systems - challenges and opportunities. Crit Rev Plant Sci. 25:303-335.

Suri IK, Prasad R, Devakumar C. 2004. Neem coating of urea-present status and future trends. Indian J Fertil. 49:21-24.

Thind HS, Bijay-Singh, Pannu RPS, Yadvinder-Singh, Varinderpal-Singh, Gupta RK, Gobinder-Singh, Kumar Ajay, Vashistha M. 2010. Managing neem (Azadirachta indica)coated urea and ordinary urea in wheat (Triticum aestivum) for improving nitrogen-use efficiency and high yields. Indian J Agr Sci. 80(11):960-964.

Thiyagarajan M, Aruna Geetha S, Balasubramanian V. 2000. Assessing genotypic variation in $\mathrm{N}$ requirements of rice with a chlorophyll meter. Int Rice Res Notes. 25(1):23-24.

Timsina J, Connor DJ. 2001. Productivity and management of rice-wheat cropping systems: issues and challenges. Field Crops Res. 69:93-132.

Trenkel ME. 1997. Improving fertilizer use efficiency: controlled-release and stabilized fertilizers in agriculture. Paris (France): International Fertilizer Industry Association.

Trenkel ME. 2007. Improving fertilizer use efficiency controlled-release and stabilized fertilizers in agriculture. Paris (France): International Fertilizer Industry Association. p. 9.

Trenkel ME, Wichmann W, Kummer KF. 1988. New challenges for the world fertilizer industry with regard to agriculture. Monte Carlo: IFA Agro-Economics Committee.

Wade B. 2009. Increasing crop productivity through nitrogen technologies. In: Proceedings of the Fertilizer Association of India Annual Seminar on Fertilizer Policy for Sustainable Agriculture; 2009 Dec 3-5; Hyderabad, India: The Fertilizer Association of India. p. 1-9.

Wang F. 1996. Modelling nitrogen transport and transformations in soils subject to environmentally friendly fertilization practices [Research thesis]. [Haifa (Israel)]: Technion - Israel Institute of Technology.

Wang G, Dobermann A, Witt C, Sun Q, Fu R. 2001. Performance of site-specific nutrient management for irrigated rice in Southeast China. Agron J. 93:869-878.

Wang Z, Cleemput O van, Demeyer P, Baert L. 1991. Effect of urease inhibitors on urea hydrolysis and ammonia volatilization. Biol Fertil Soil. 11:43-47.

Wang ZP, Cleemput O van, Baert L. 1994. Movement of urea and its hydrolysis products as influenced by moisture content and urease inhibitors. Biol Fertil Soil. 22(1-2):101-108.

Watson CJ, Miller H, Poland P, Kilpatrick DJ, Allen MD B, Garrett MK, Christianson CB. 1994. Soil properties and the ability of the urease inhibitor $\mathrm{N}$-(n-butyl) thiophosphoric triamide ( $n \mathrm{BTPT})$ to reduce ammonia volatilization from surface-applied urea. Biol Fertil Soil. 26:1165-1171. 
Wopereis MCS, Donovan C, Nebié B, Guindo D, N’Diaye MK. 1999. Soil fertility management in irrigated rice systems in the Sahel and Savanna regions of West Africa. Part I - agronomic analysis. Field Crops Res. 61:125-145.

Wu L, Liu M. 2008. Preparation and properties of chitosancoated NPK compound fertilizer with controlledrelease and water-retention. Carbohydr Polym. 72:240-247. doi: 10.1016/ j.carbpol.2007.08.020

Xiaobin W, Jingfeng X, Grant CA, Bailey LD. 1994. Effects of placement of urea with a urease inhibitor on seedling emergence, $\mathrm{N}$ uptake and dry matter yield of wheat. Can $\mathrm{J}$ Soil Sci. Nov:449-452.

Zhang ZJ, Wang GH. 1999. Soil phosphorus status and its environmental effect in Jiaxing district, Zhejiang (in Chinese). Bull Sci Technol. 15:377-381.

Zvomuya F, Rosen CJ, Russelle MP, Gupta SC. 2003. Nitrate leaching and nitrogen recovery following application of polyolefin-coated urea to potato. J Environ Qual. 32:1015-1024. 